\title{
Contamination of the Bay of Biscay by polycyclic aromatic hydrocarbons (PAHs) following the T/V "Erika" oil spill
}

\author{
Jacek Tronczyński ${ }^{a}$, Catherine Munschy, Karine Héas-Moisan, Nadège Guiot, Isabelle Truquet, \\ Nathalie Olivier, Sophie Men and Audrey Furaut
}

Ifremer, Département des polluants chimiques, rue de l'Ile d'Yeu, BP 21105, 44311 Nantes Cedex 03, France

Received 10 February 2004; Accepted 14 September 2004

\begin{abstract}
An investigation was carried out into the PAH chemical contamination resulting from the "Erika" tanker fuel spillage of December 1999 along the French coast of the Bay of Biscay. A qualitative and quantitative assessment was conducted of this contamination in water, suspended particulate matter, sediments, and in intertidal molluscs. The chemical composition of PAHs in pre-spill and post-spill samples was determined and used to distinguish the "Erika's" fuel as the source of PAHs in the coastal environment of the Bay of Biscay. Changes in concentrations of PAHs were also assessed. The GC-MS analysis made it possible to identify and quantify parent unsubstituted PAHs, alkyl-substituted PAHs (C-PAH) and sulfur heterocycle unsubstituted and alkyl substituted compounds (SPAH and C-SPAH). The results of this study demonstrated that heavily oil-contaminated shorelines, including beaches, rocky coasts as well as sandy sediments apparently became reservoirs of spilled fuel and these continued to contaminate seawater, suspended particulate matter and mussels with PAHs. These conclusions were borne out by the following observations: (1) the pattern changes in PAH composition after the "Erika" oil spill were consistent in all contaminated compartments (water, suspended particulate matter SPM, intertidal sediments and molluscs), (2) the compositional patterns of PAHs after the "Erika" oil spill in contaminated water, SPM, intertidal sediments and molluses constantly included alkyl-substituted phenanthrenes, pyrenes, chrysenes and sulfur heterocycle compounds in higher relative abundances than those in the pre-spill samples of these compartments, (3) the relative abundances of different suites of PAHs at contaminated sites were similar to those of weathered "Erika" fuel, (4) consistent and visible temporal decline in concentrations for water, SPM and molluscs, (5) the geographical contiguity of the stations with high concentrations of PAHs in molluscs matched the extent of the shoreline contamination by the spilled fuel. The increase in the contamination levels before and after the spill, together with the significant change in the pattern of PAH composition provide evidence of the intense and long-term chemical contamination of the "Erika's" fuel and of the damage to natural marine resources resulting from such contamination by toxic oil components.
\end{abstract}

Key words: Chemical contamination / Water / Suspended particulate matter / Sediments / Marine molluscs / North-East Atlantic / The "Erika" oil spill

Résumé - Contamination du golfe de Gascogne par des hydrocarbures aromatiques polycycliques (HAP) après le naufrage de N/T «Erika ». La contamination chimique par des hydrocarbures aromatiques polycycliques, HAP, issus du fioul déversé par le pétrolier «Erika» en décembre 1999, a été étudiée le long des côtes françaises du golfe de Gascogne. L'évaluation qualitative et quantitative de cette contamination a été effectuée dans l'eau, dans les matières en suspension (MES), les sédiments et les mollusques intertidaux. La composition chimique des HAP a été déterminée dans les échantillons collectés avant et après le naufrage et utilisée pour identifier des HAP en provenance du fioul de l' «Erika» dans l'environnement côtier du golfe de Gascogne. Les changements de concentrations des HAP ont été également déterminés. Les analyses par CPG-SM ont permis l'identification et la quantification des HAP parents non-substitués (HAP), leurs dérivés alkylés substitués (C-HAP), ainsi que des hétérocycliques soufrés et leurs homologues alkylés (SHAP et C-SHAP). Les nappes et les poches du fioul se sont répandues et enfouies sur les côtes maritimes fortement touchées, sur des sites tels que des plages, des côtes rocheuses ainsi que dans certains sédiments sablonneux. Celles-ci ont vraisemblablement constitué des réservoirs durables du fioul et les résultats de notre étude indiquent qu'ils ont continué, longtemps après le naufrage, à contaminer l'eau de mer, les matières en suspension et les mollusques par des HAP. Ces conclusions ont été obtenues suite aux observations suivantes : (1) après le naufrage de l'«Erika» les changements de la composition

\footnotetext{
a Corresponding author: jtronczy@ifremer.fr
} 
et des empreintes des HAP déterminés dans tous les compartiments contaminés (eau, MES, sédiments intertidaux et mollusques) ont été similaires, (2) après le naufrage de l' «Erika», on retrouve régulièrement dans tous les compartiments contaminés les phénanthrènes, pyrènes/fluoranthènes, et chrysènes alkylés ainsi que les hétérocycliques soufrés dans des proportions relatives plus importantes que dans les échantillons de même compartiment avant le naufrage, (3) sur les sites contaminés, les proportions relatives des différents groupes des HAP ont été similaires à celles caractéristiques du fioul de l' «Erika» vieilli dans l'environnement, (4) les tendances temporelles des niveaux en HAP concordantes ont été observées dans l'eau de mer, MES et mollusques, (5) les positionnements géographiques des stations avec forte contamination des mollusques par des HAP correspondent bien à l'intensité de la contamination des côtes par le fioul déversé. En conséquence, il apparaît qu'aussi bien l'augmentation des niveaux de la contamination que le changement significatif de la composition des HAP après le naufrage fournissent l'évidence d'une contamination chimique forte et de longe durée par le fioul de l' «Erika», et que la contamination par des composés toxiques du fioul entraîne des dommages aux ressources naturelles.

\section{Introduction}

As a rule, major oil spills in the marine environment result in a significant chemical contamination of the various parts of the marine ecosystems by petroleum hydrocarbons. Assessing the damage to natural resources caused by such contamination due to toxic oil components therefore requires a sizeable research effort and this has not been fully achieved to date.

Especially in local terms, oil spills account for very significant inputs of hydrocarbons into the marine environment, including toxic compounds such as certain polycyclic aromatic hydrocarbon (PAHs). Quantities amounting to several tons of $\mathrm{PAH}$ discharged by a given oil spill in a major disaster come into the same category as other large scale environmental inputs and emissions of these compounds (e.g., annual emissions of PAHs in Europe per source category were estimated for road transport combustion to be about $1500 \mathrm{ty}^{-1}$ and $6800 \mathrm{ty}^{-1}$ for fuel combustion [excluding transport], Vallack et al. 1998). Estimates of annual inputs of PAHs into the North Western Mediterranean sea were reported to be about $60 \mathrm{ty}^{-1}$ (Tolosa et al. 1996). These figures compare to the amounts of PAHs spilled into the Bay of Biscay during the recent $T / V$ Erika and the $T / V$ Prestige disasters which could be estimated to range from 60 to 660 and from 150 to $1650 \mathrm{t}$ respectively (the ranges are low estimates for the summed concentrations of 16 EPA-US-Environmental Protection Agency-priority parent PAHs and high estimates for the sum of whole suites of parent and alkyl compounds identified and quantified in these fueloils). There may be insufficient recognition of the fact that accidental oil spills discharge huge quantities of persistent compounds such as PAHs into the relatively restricted seashore, bay and beach areas in an almost instantaneous manner.

It is commonly admitted that chemical surveys related to oil spills now provide reliable spatial and temporal data for assessing the contamination of the marine ecosystems. These data can contribute to the reconstruction of the mass balance of the spilled oil. The chemical data comprise both sensitive and accurate qualitative and quantitative indicators of the environmental impacts induced by these disasters in the various environmental compartments of the marine ecosystems. Chemical data are also needed and used to assess the exposure of marine biota and to evaluate the toxicological or ecotoxicological consequences of oil spills. Finally, further use is also made of the data on the chemical contamination of the seafood products by toxic carcinogenic PAHs after oil spills as criteria in health risk assessment, in the closing and opening of shellfish and fishery areas and when authorizing or not the marketing of these products.
The assessment of the chemical contamination of the Biscay coast of France after the T/V Erika disaster is an important and complimentary part of the research and scientific surveys carried out for the evaluation of the ecological consequences of this oil spill. Our assessment of the chemical contamination was conducted from December 1999 and lasted three years. The study focused firstly on the characterisation of chemical contamination by aromatic polycyclic compounds of the marine sediments, water, suspended matter and molluscs including:

i. the qualitative identification of the changing composition and chemical fingerprints in the series of PAHs and heterocycle sulfur compounds and their mono-, di-, tri- and tetra- alkyl homologues;

ii. the quantitative evaluation of changing levels of concentrations of the same suite of aromatic compounds.

Secondly, the study consisted in the assessment of the spatial extent and temporal trends of the chemical contamination by PAHs and their homologues in the Bay of Biscay.

In this article we describe a preliminary overview of the selected results, and explain the adopted methods and strategies of our study. By using a few examples, we integrate obtained data on the chemical contamination of the different environmental compartments by PAHs after the Erika oil spill in the Bay of Biscay. We also report reference concentrations of PAHs and their homologues, which have been determined and used in this study in order to compare chemical contamination before and after the Erika disaster.

\section{Methods}

\subsection{Sample collection and chemical protocols}

\section{Water and suspended particulate matter (SPM)}

The stations were sampled at off-shore and coastal sites for water and SPM on board the R/V Thalia, an oceanographic research vessel, during different sampling cruises in February and March 2000, and May 2002. The temporal surveys were carried out at Vilaine Bay at two stations, Dumet Island (a short sampling survey from March to June 2000) and the Pen Bron site at the entry to the Croisic Tract (monthly sampling between March 2000 and May 2002). The sampling was made from the rubber dinghy (at Dumet station) and directly from the shore (at Pen Bron station). All station locations are shown in Figure 1, including coastal and off-shore stations sampled before the Erika oil spill in February 1999. 


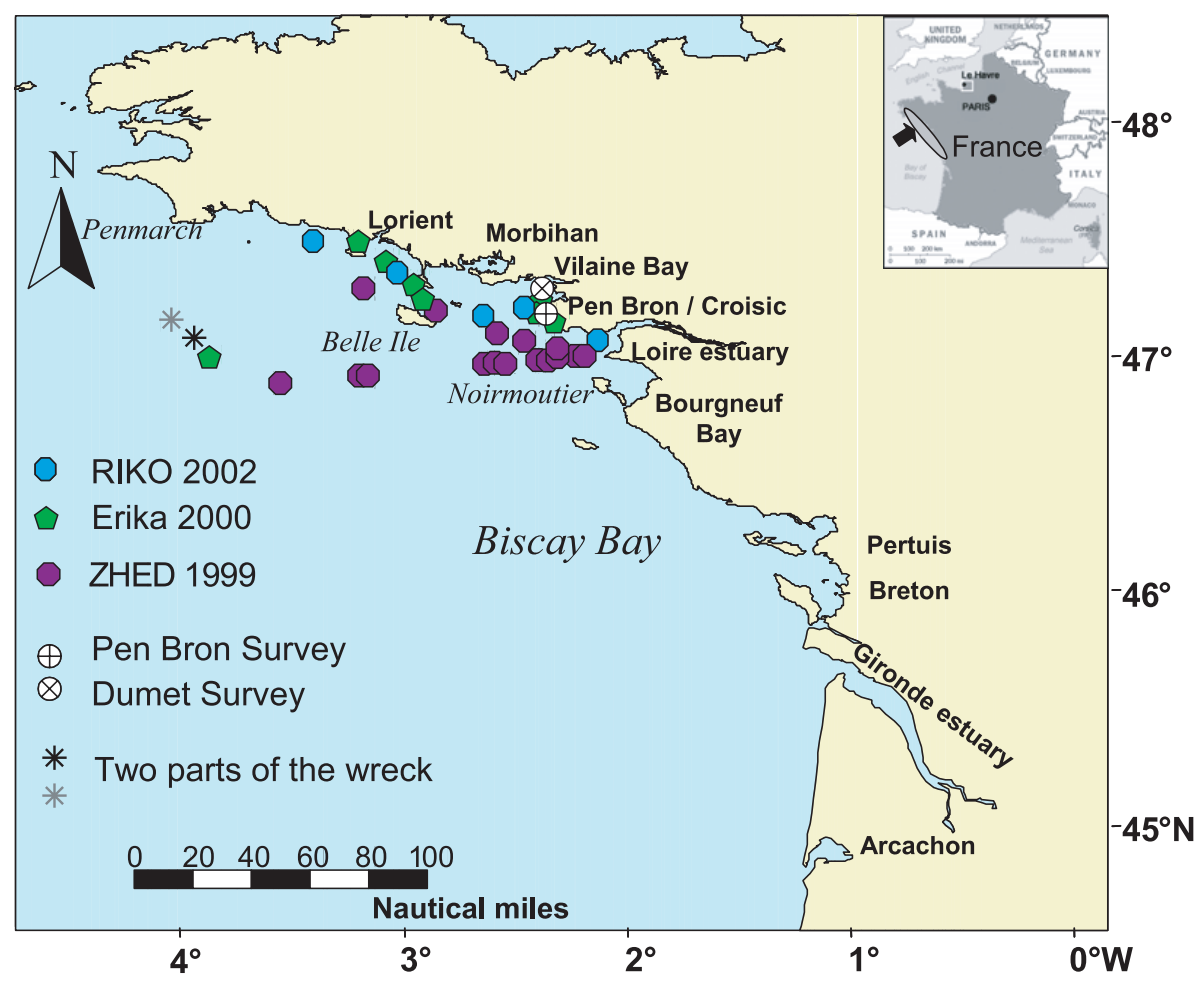

Fig. 1. Location of sampling sites in the Bay of Biscay for water samples. The sampling cruises ZHED 1999 and ERIKA 2000 were carried in February 1999 and February 2000, before and after the Erika spill respectively. Temporal surveys were carried out at Pen Bron and Dumet sites.

The seawater samples were taken at subsurface depth (between 2 and $4 \mathrm{~m}$ ), except for the samples adjacent to the $\mathrm{T} / \mathrm{V}$ Erika wreck area, which were collected in a water column at different depths: surface, intermediate (20-60 m) and bottom, slightly below 100 meters. The samples were collected by pumping seawater through all PTFE tubing and pumps (AstiPure ${ }^{\mathrm{TM}}$ PFD pneumatic pumps placed onboard) into stainless steel or glass 20-L containers for PAH analyses and into $1 \mathrm{~L}$ to $10 \mathrm{~L}$ glass bottles for SPM determinations. The off-shore and coastal samples were filtered and extracted onboard in the vessel's clean laboratory. The survey samples were brought to the land-based laboratory for further treatment. The water samples were filtered through GF/F fiberglass filters $\left(0.7 \mu \mathrm{m}\right.$ nominal porosity), pre-baked at $450{ }^{\circ} \mathrm{C}$. The filtered seawater was extracted by solid phase extraction on XAD-2 (polystyrene-divinylbenzene) resins $(370 \mathrm{~mm} \times$ $19 \mathrm{~mm}$ columns) with peristaltic suction pumps for dissolved PAH analysis. The analytes were eluted with ca. $100 \mathrm{ml}$ of dichloromethane DCM and these extracts were stored at about $3{ }^{\circ} \mathrm{C}$ until further treatment. The SPM was determined gravimetrically on $47 \mathrm{~mm} \mathrm{GF} / \mathrm{F}$ pre-baked and pre-weighted fiberglass filters. The filters containing SPM for particulate PAH analyses were torn into pieces, put into the clean glass jars, fitted with baked aluminium paper and teflon-lined caps, and then frozen to $-20{ }^{\circ} \mathrm{C}$ until extraction. The seawater and SPM sample were only brought into contact with Teflon, stainless steel or glass during collection and further treatment and were not exposed to hydrocarbon vapours. The amounts of water filtered for particulate PAH analyses were between 100 to
$450 \mathrm{~L}$ and the corresponding volumes of water extracted for dissolved PAH analyses were between 90 to $180 \mathrm{~L}$.

\section{Sediments}

The sampling of surface sediments was conducted in the Bay of Biscay in February and March 2000 at the area adjacent to the Erika wreck and at the stations in the non-protected zone of the Guérande and the Mès salt marshes. In July 2000 this was pursued at the stations located between Pertuis Breton in the South and Penmarc'h Point in the North (Fig. 2). The sediment samples of the National Monitoring Network (Réseau National d'Observation - RNO) collected in the Bay of Biscay before the Erika oil spill in June 1999 were used as a reference for determining pre-accident levels and composition of PAHs in the Biscay surface sediments. For purposes of direct comparison, the numerous stations were re-sampled during July 2000. All "RNO" and Erika locations are shown in Figure 2.

Subtidal surface sediment samples were collected on board the R/V Thalia, between 6 and $130 \mathrm{~m}$ and using a Reineck stainless steel sediment box corer. Intertidal sediment sample collection was performed at about the mean lower low water line. All samples were taken from the undisturbed surface of the sediment (top $0-2 \mathrm{~cm}$ ) with a stainless steel spoon or spatula. The sediments were then stored in clean and prebaked glass jars, capped with aluminium foil and frozen. The subsamples were taken in order to determine the density of the solids and grain-size distribution of the particles. The sediments to be used for chemical analyses were freeze-dried 


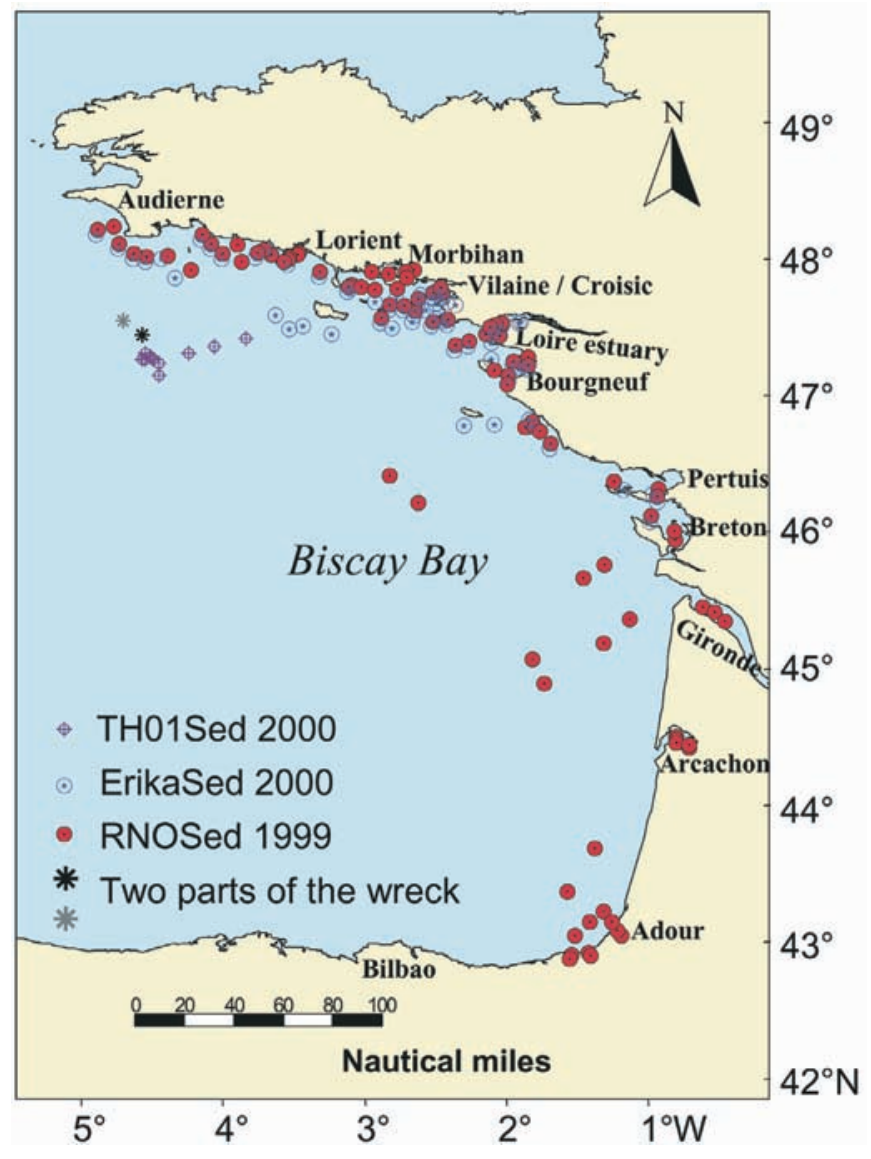

Fig. 2. Location of sampling sites in the Bay of Biscay for sediment samples. Sampling sites are indicated for different cruises carried before (RNOSed 1999) and after (TH01 and Erika-sed 2000) the Erika spill. Sampling before the accident was carried from the Audierne Bay in the north to the Adour estuary in the south near the Spanish frontier. After the accident the same stations were resampled but limited to the Pertuis Breton in the south and a few additional stations were sampled (ex. along the transect from the wreck to Belle Ile and nearby l'Ile d'Yeu).

and sieved at $2 \mathrm{~mm}$ to remove gravel-size particles. About 5 to $10 \mathrm{~g}$ of dry weight sediment samples were twice extracted with an accelerated solvent extractor (ASE, Dionex) with DCM. The elemental sulfur was removed from sediment extracts with copper powder activated with hydrochloric acid.

\section{Molluscs}

The mussel (Mytilus edulis) and Pacific oyster (Crassostrea gigas) samples were collected once a month in 2000 and every other month in 2001 and 2002. Samples were taken from 12 stations situated between the Morbihan to Vendée coasts (Fig. 3). Among these locations, five are regularly sampled for $\mathrm{PAH}$ analyses within the framework of the National Monitoring Network program (RNO). In December 1999, a few selected stations were also sampled just before the wash up of the oil slicks on the coasts, thus providing timely and seasonal reference for contamination of these locations by PAHs.
Samples were collected by hand and stored in sealed plastic bags at $-20{ }^{\circ} \mathrm{C}$ until further analyses. Shellfish sampling was performed so as to avoid contamination by coated fuel. Depending on the species, at least 10 to 50 specimens of controlled shell sizes were pooled as a composite sample representative of each location. Prior to extraction, whole shucked molluscs were homogenized, using a tissumizer and then freeze-dried. About 5 grams of dry weight samples were extracted with ASE and with dichloromethane, and then most of the lipids were removed from the extracts by Gel Permeation Chromatography (BIO-Beads SX-3 200-400 Mesh, $460 \mathrm{~mm} \times 26 \mathrm{~mm}$ column). Small aliquots of samples were taken just before extraction in order to determine the dry weight.

The clean-up and fractionation of all organic extracts of water, sediments, SPM and mollusc samples were made by adsorption chromatography on the silica gel (on top) and alumina (on bottom) columns, with both sorbents deactivated with 5\% water (by weight). The first two fractions eluted with hexane and hexane/DCM were separately analysed for PAHs.

\subsection{Instrumental PAH analysis and quality control}

The polycyclic aromatic hydrocarbons (PAHs) determined in this study are listed in Table 1. Different suites of PAHs include unsubstituted parent compounds, alkyl-substituted homologues and unsubstituted sulfur heterocycle and their alkylsubstituted compounds. The instrumental analysis of PAHs was performed by high resolution gas chromatography using an HP 6890 gas chromatograph fitted with a 5973 mass selective detector (MSD). The PAHs were separated on the DB5-MS fused silica capillary column (coated with 5\% phenyl methyl silicone), $60 \mathrm{~m}$ in length with a $0.25 \mathrm{~mm}$ internal diameter and with helium used as a carrier gas. The injections were conducted with a Combi-PAL CTC autosampler. Two techniques of injection were used: a low volume of 1-2 $\mu$ l with an on-column port or a large volume of $20 \mu \mathrm{l}$ with an LVI Optic 2 injector. The LVI injection was used to analyse the low concentrations of PAHs, especially in selected water, SPM or sediment extracts. The mass selective detector was operated in electron impact mode at $70 \mathrm{eV}$ and for quantitative analysis of individual PAHs in the selected ion monitoring mode (SIM) in relation to perdeuterated compounds added by autosampler prior to injection (acenaphthene- $\mathrm{d}_{10}$, fluorene- $\mathrm{d}_{10}$, pyrene$\mathrm{d}_{10}$, benzo $[a]$ anthracene- $\left.\mathrm{d}_{12}\right)$. The PAHs, internal recovery and quantification standards were identified by their specific ions and retention time windows. The MSD was routinely tuned with ions 69, 219 and 502 fragments of perfluorotributylamine.

The identification of individual compounds was based on the single mass fragment ion characteristic of the compound and their retention time. The concentrations of compounds were determined in extracts with an eight-point calibration curve (linear regression) made for each compound and with laboratory prepared calibration solutions. The calibration curves considered came within the range of the concentrations of the analytes in the samples. A separate calibration curve was used for very low concentrations of PAHs in the extracts. Calibration solutions were prepared in iso-octane by appropriate dilutions (by weight). Prior to injection, deuterated surrogate 


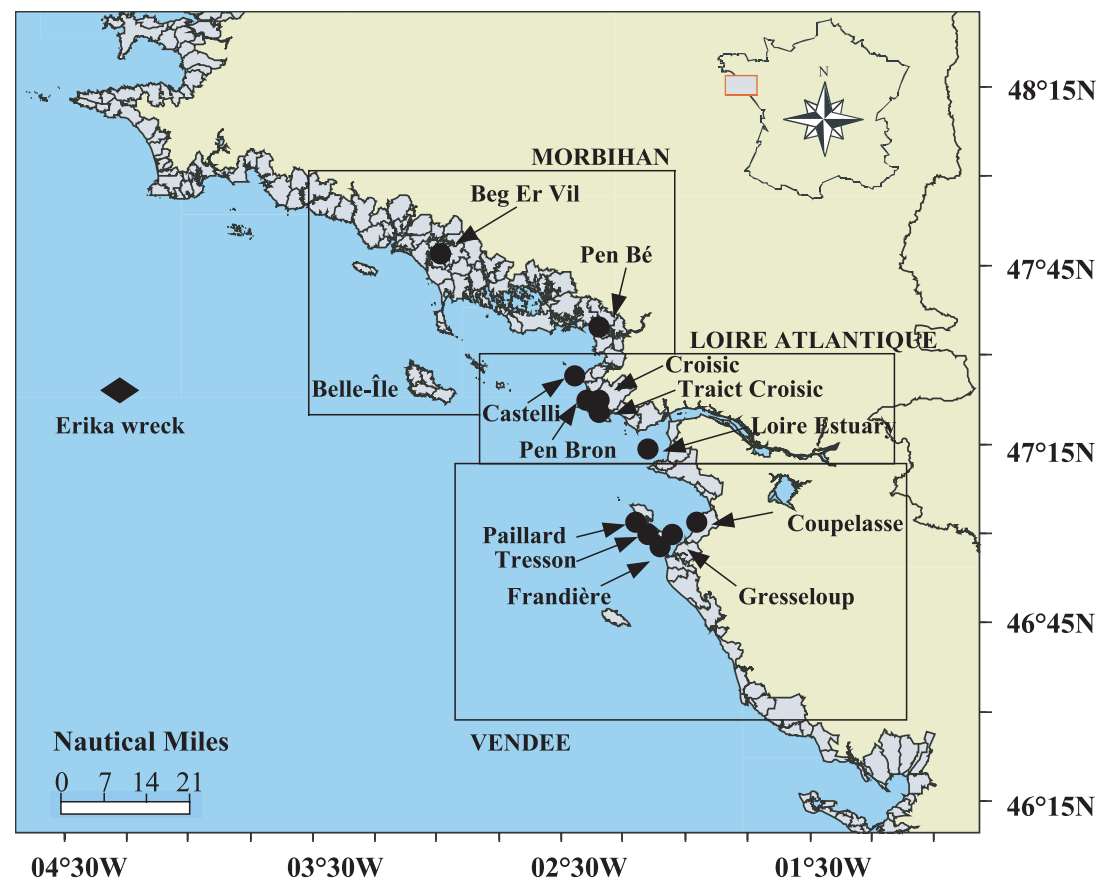

Fig. 3. Location of sampling sites for mollusc samples collected from December 1999 to December 2002.

compounds were automatically added into each extract and into external calibration solutions. These were subsequently used as an internal quantitative standard with each corresponding analyte Table 1.

Internal QA/QC procedures including laboratory and field blanks, analyses of replicate samples for precision determination, use of internal recovery perdeuterated standards (phenanthrene- $\mathrm{d}_{10}$, perylene- $\mathrm{d}_{12}$ or benzo[ $\left.e\right]$ pyrene- $\mathrm{d}_{12}$ ) added to each sample before extraction made it possible to verify losses of analytes during the entire sample work-out. Samples with recoveries below $60 \%$ were rejected or re-analysed. Analyses of Standard Reference Materials (SRM 1491, SRM 2977 from the National Institute of Standards and Technology NIST and EC-2 from National Water Research Institute NWRI) were routinely incorporated into each batch of samples and used to monitor the overall accuracy of the method. The method detection limits of analytes were individually calculated for the sample and depended on the size of the sample used for extractions, the final dilution of the extract, injection technique, and the relative response factor of the analytes.

The laboratory proficiency for PAHs analysis is also evaluated through participation in the QUASIMEME (Quality Assurance of Information for Marine Environmental Monitoring in Europe) intercomparison exercises. The laboratory has also participated in the European project of the preparation of certified materials for PAH analysis (BROC biological references for organic contaminants).

\section{Results}

\subsection{Composition of the fuel}

The fuel transported by the T/V Erika came from the Flanders refinery in Dunkirk and was a highly viscous No. 2 fuel-oil (a No. 6 fuel oil according to the British classification) containing about $42-50 \%$ of aromatic hydrocarbons including $14 \%$ sulfur-containing aromatic compounds, $23-36 \%$ resins and asphaltens, and $22-30 \%$ saturated hydrocarbons (source: IFP Institut Français du Pétrole). The major PAHs were alkyl substituted homologues of naphtalenes, phenanthrenes/anthracenes, fluoranthenes/pyrenes and chrysenes. The alkyl-naphtalene series were still the most abundant among other alkyl compounds, which is commonly observed in fresh oils (Wang et al. 1997). The Erika's fuel also contained heterocyclic sulfur compounds, such as dibenzothiophene and its alkyl derivatives, benzonaphthothiophenes and their alkyl derivatives. The year long survey of the weathering and transformation of the Erika's fuel collected from the rocky shoreline showed no signs of significant change in the PAH pattern composition (Tronczyński et al. 2001).

\subsection{Water and SPM}

\section{Pre-spill and post-spill composition and concentration changes of dissolved and particulate PAHs}

The archived organic extracts of filtered water samples and SPM filters collected before the disaster in the coastal waters of the Loire-Atlantique region were re-analysed for the dissolved and particulate PAHs. These results provide limited reference of pre-spill background concentrations and a chemical fingerprint of dissolved and particulate PAHs for the area under study. The pre-spill results were compared to the results of the analysis of samples taken in different periods after the Erika's oil spill. The compositional changes and higher concentrations of different suites of dissolved and particulate PAHs consistent with the Erika's fuel, clearly demonstrate that 
Table 1. List of parent and alkyl substituted PAHs and sulfur heterocyclic PAHs determined, abbreviations, molecular weights, and internal standards used as references for quantitation.

\begin{tabular}{|c|c|c|c|}
\hline Compound name & Abbreviation & Molecular Weight & Internal standard \\
\hline \multicolumn{4}{|c|}{ PAHs and alkyl substituted homologues } \\
\hline Naphthalene & Naphtalene & 128 & Acenaphthene- $\mathrm{d}_{10}$ \\
\hline C1-naphthalenes & $\mathrm{C} 1-\mathrm{N}$ & 142 & Acenaphthene- $\mathrm{d}_{10}$ \\
\hline C2-naphthalenes & $\mathrm{C} 2-\mathrm{N}$ & 156 & Acenaphthene- $\mathrm{d}_{10}$ \\
\hline C3-naphthalenes & $\mathrm{C} 3-\mathrm{N}$ & 170 & Acenaphthene- $\mathrm{d}_{10}$ \\
\hline C4-naphthalenes & $\mathrm{C} 4-\mathrm{N}$ & 184 & Acenaphthene- $\mathrm{d}_{10}$ \\
\hline Acenaphthylene & Acenaphthylene & 152 & Acenaphthene- $\mathrm{d}_{10}$ \\
\hline Acenaphthene & Acenaphthene & 154 & Acenaphthene- $\mathrm{d}_{10}$ \\
\hline Fluorene & Fluorene & 166 & Fluorene- $\mathrm{d}_{10}$ \\
\hline C1-fluorenes & $\mathrm{C} 1-\mathrm{F}$ & 180 & Fluorene- $\mathrm{d}_{10}$ \\
\hline C2-fluorenes & $\mathrm{C} 2-\mathrm{F}$ & 194 & Fluorene- $\mathrm{d}_{10}$ \\
\hline Phenanthrene & Phenanthrene & 178 & Fluorene- $\mathrm{d}_{10}$ \\
\hline C1-phenanthrenes/anthracenes & $\mathrm{C} 1-\mathrm{P}$ & 192 & Fluorene- $\mathrm{d}_{10}$ \\
\hline C2-phenanthrenes/anthracenes & $\mathrm{C} 2-\mathrm{P}$ & 206 & Fluorene- $\mathrm{d}_{10}$ \\
\hline C3-phenanthrenes/anthracenes & C3-P & 220 & Fluorene- $\mathrm{d}_{10}$ \\
\hline Anthracene & Anthracene & 178 & Fluorene- $\mathrm{d}_{10}$ \\
\hline Fluoranthene & Fluoranthene & 202 & Pyrene-d $\mathrm{d}_{10}$ \\
\hline Pyrene & Pyrene & 202 & Pyrene- $d_{10}$ \\
\hline C1-pyrenes/fluoranthenes & C1-PY & 216 & Pyrene- $d_{10}$ \\
\hline C2-pyrenes/fluoranthenes & C2-PY & 230 & Pyrene- $\mathrm{d}_{10}$ \\
\hline Benz $[a]$ anthracene & $\mathrm{B}[a]$ anthr & 228 & Benz $[a]$ anthracene- $\mathrm{d}_{12}$ \\
\hline Triphenylene & Triphen & 228 & Benz $[a]$ anthracene- $\mathrm{d}_{12}$ \\
\hline Chrysene & $\mathrm{CHR}$ & 228 & Benz $[a]$ anthracene- $\mathrm{d}_{12}$ \\
\hline C1-chrysene & $\mathrm{C} 1-\mathrm{CHR}$ & 242 & Benz $[a]$ anthracene- $\mathrm{d}_{12}$ \\
\hline C2-chrysene & $\mathrm{C} 2-\mathrm{CHR}$ & 256 & Benz $[a]$ anthracene- $\mathrm{d}_{12}$ \\
\hline Benzo $[b]$ fluoranthene & BFLs & 252 & Benz $[a]$ anthracene- $\mathrm{d}_{12}$ \\
\hline Benzo $[k]$ fluoranthene & & 252 & Benz $[a]$ anthracene- $\mathrm{d}_{12}$ \\
\hline Benzo[j]fluoranthene & & 252 & Benz $[a]$ anthracene- $\mathrm{d}_{12}$ \\
\hline C1- Benzofluoranthenes & C1-BFLs & & Benz $[a]$ anthracene- $\mathrm{d}_{12}$ \\
\hline Benzo $[e]$ pyrene & $\mathrm{B}[e]$ py & 252 & Benz $[a]$ anthracene- $\mathrm{d}_{12}$ \\
\hline Benzo $[a]$ pyrene & $\mathrm{B}[a]$ py & 252 & Benz $[a]$ anthracene- $\mathrm{d}_{12}$ \\
\hline Perylene & Perylene & 252 & Benz $[a]$ anthracene- $\mathrm{d}_{12}$ \\
\hline Indeno $[1,2,3-c d]$ pyrene & Indeno-Pyr & 276 & Benz $[a]$ anthracene- $\mathrm{d}_{12}$ \\
\hline Dibenz $[a, h]$ anthracene & DBA & 278 & Benz $[a]$ anthracene- $\mathrm{d}_{12}$ \\
\hline Benzo[ghi]perylene & $\mathrm{B}(g h i)$ perylene & 276 & Benz $[a]$ anthracene- $\mathrm{d}_{12}$ \\
\hline \multicolumn{4}{|c|}{ Sulfur-heterocyclic compounds and alkyl substituted homologues } \\
\hline Dibenzothiophene & DBT & 184 & Fluorene- $\mathrm{d}_{10}$ \\
\hline C1-dibenzothiophenes & C1-DBT & 198 & Fluorene- $\mathrm{d}_{10}$ \\
\hline C2-dibenzothiophenes & C2-DBT & 212 & Fluorene- $\mathrm{d}_{10}$ \\
\hline C3-dibenzothiophenes & C3-DBT & 226 & Fluorene- $\mathrm{d}_{10}$ \\
\hline Benzonaphthothiophenes & BNTs & 234 & Pyrene- $\mathrm{d}_{10}$ \\
\hline C1-benzonaphthothiophenes & C1-BNTs & 248 & Pyrene- $\mathrm{d}_{10}$ \\
\hline
\end{tabular}

seawater was contaminated by the Erika fuel-PAHs after the shipwreck.

Both a very notable change of pattern and an increase in concentrations of dissolved PAHs in post-spill samples were observed at the coastal stations along heavily oiled sea shores (Fig. 4). Following the disaster, the most prominent suites of dissolved PAHs were alkyl-substituted phenanthrenes, naphthalenes and alkyl-homologues of dibenzothiophenes. The similar patterns of PAH composition were observed in the offshore samples collected more than two months after the disaster in the whole water column of $100 \mathrm{~m}$ depth near the Erika wreck, as well as in most of the coastal samples of the temporal survey at the Pen Bron location. These chemical fingerprints of PAH abundances in post-spill water samples were broadly consistent with the PAH composition pattern in the weathered Erika fuel samples taken from the intertidal rocks adjacent to the Croisic location (Tronczyński et al. 2001). In addition, the relative abundance of certain unsubstituted PAHs also changed after the disaster. In contaminated post-spill samples, for example, pyrene concentrations were often higher than those of fluoranthene. This result contrasts with the chronic contamination of the coastal and estuarine waters by PAHs, generally characterized by concentrations of dissolved fluoranthene slightly higher than pyrene (Maldonado et al. 1999). As a matter of fact, in the Erika's fuel, pyrene was markedly more concentrated than fluoranthene (in the fuel samples taken off 


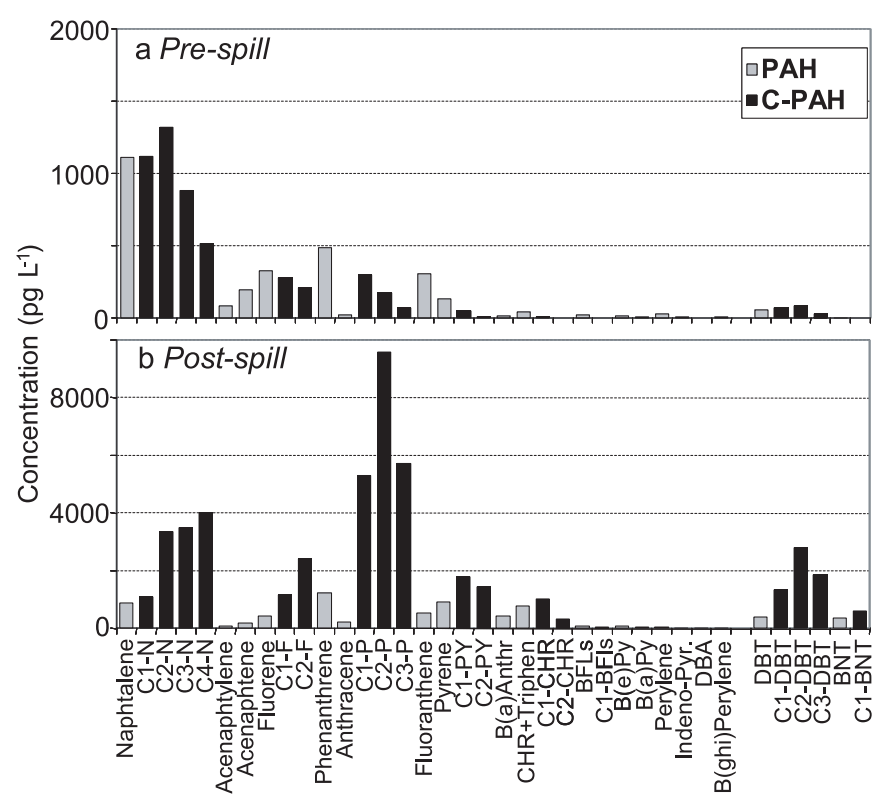

Fig. 4. Distribution pattern of dissolved PAHs $\left(\mathrm{pg} \mathrm{L}^{-1}\right)$ in coastal waters for a sample collected at site Le Croisic (open waters) before the spill in February 1999 (a) and after the spill in February 2000 (b).

intertidal rocks, the $\mathrm{Fl} / \mathrm{Py}$ ratio of about 0.16 did not change for more than 8 months, Tronczyński et al. 2001). The compositional changes and different diagnostic ratios clearly point to Erika-PAH presence in the water samples after the disaster. These changes corroborate the quantitative results of the considerable increase in the concentrations of dissolved and particulate PAHs.

The ranges of summed concentrations of different suites of dissolved and particulate PAH in pre- and post-spill samples feature in Tables 2 and 3. After the oil spill, the highest summed concentrations of alkyl-substituted C-PAHs were determined at the coastal stations adjacent to shores heavily impacted by the Erika's fuel. In the sampling period of 2000 , concentrations of C-PAHs at these stations ranged from 17 to $118 \mathrm{ng} \mathrm{L}^{-1}$ seawater for dissolved compounds and from about 500 to more than $16500 \mu \mathrm{g} \mathrm{kg}^{-1} \mathrm{dw}$ SPM for particulate compounds. The concentrations of unsubstituted PAHs ranged for the same set of samples from 3.9 to $21 \mathrm{ng} \mathrm{L}^{-1}$ and from 360 to $2500 \mu \mathrm{g} \mathrm{kg}^{-1} \mathrm{dw}$ of dissolved and particulate compounds respectively. The highest concentrations were observed for both dissolved and particulate phases as well as for both suites of alkyl and unsubstituted PAHs at the same stations and the same periods. On the other hand, an increase in concentrations of alkyl PAHs was noticeably more prominent than that of their parent unsubstituted counterparts, hence visibly shifting the relative proportion of alkyl and parent compounds. A brief reappraisal of these results will be made below.

Post-spill concentrations were comparatively much lower in the waters sampled at stations that were situated further off-shore, ranging from 0.7 to 2.8 and from 2.9 to $8.9 \mathrm{ng} \mathrm{L}^{-1}$ seawater for dissolved, and from 57 to 130 and from 77 to $156 \mu \mathrm{g} \mathrm{kg}^{-1} \mathrm{dw}$ SPM for particulate, parent and alkyl suites of PAHs respectively. These very low ranges of concentrations in the off-shore waters overlap with concentrations determined in these waters in pre-spill samples (Tables 2 and 3). These results appear to suggest fairly low contamination of the offshore seawaters by Erika-PAHs. However, as previously noted, the whole water column in the wreck area showed the chemical signature of Erika fuel, two months after the shipwreck, suggesting a rather large mass of contaminated seawater in this region. It is obvious that at that time the Erika wreck was apparently the real reservoir of the fuel that continued to contaminate quite large water masses by Erika spilled PAHs. However, in all pre-spill reference samples the concentrations of dissolved naphthalene and alkyl naphthalenes were relatively elevated (Fig. 4), indicating chronic contamination of seawater by these compounds and therefore should be considered as less representative of Erika-PAHs. What is more, if no extra precautions are taken, these and other two-ring low molecular PAHs are prone to evaporative losses during sample laboratory treatment (Short et al. 1996a). Summed concentrations of parent and alkyl PAHs without low molecular compounds are also described in Tables 2 and 3. These concentrations are a somewhat better gauge of the increase in the seawater contamination by PAHs after the Erika oil spill. For these sets of data, the concentrations of dissolved unsubstituted PAHs were highly correlated with their alkyl homologues $\left(R^{2}=0.72, N=14\right.$ and $R^{2}=0.96, N=51$ ) in all pre-spill and all post-spill samples respectively (Fig. 5). Nevertheless, the absolute proportions of alkyl compounds were much higher in the post-spill samples, and consequently the slopes of linear regression lines were significantly different in post-spill and pre-spill sets of data (Fig. 5). This result enabled us to explicitly distinguish between contaminated and uncontaminated water samples by Erika-PAHs.

\section{Temporal survey}

A temporal survey of water contamination by PAHs was carried out at Pen Bron station, the entry to the Croisic Tract, between March 2000 and May 2002. The sampling of about $100 \mathrm{~L}$ water samples was completed once per month at high tide. The results of the summed concentrations of different suites of dissolved and particulate PAHs are described in Figure 6. These results are representative of the concentrations of PAHs in waters adjacent to heavily oiled shorelines after the Erika oil spill. In fact, a slick of a few tons of Erika fuel was buried at the bottom of the sandy sediments in this region, at the entry to the Croisic Tract.

The temporal variation of concentrations of PAHs was very similar for both the water phase and the suspended particulate matter phase. The relatively higher concentrations, ranging for dissolved compounds from 3.8 to $19 \mathrm{ng} \mathrm{L}^{-1}$ of $\Sigma \mathrm{PAH}$ and from 14 to $118 \mathrm{ng} \mathrm{L}^{-1}$ of $\Sigma \mathrm{C}$-PAH and for particulate compounds from 700 to $16500 \mu \mathrm{g} \mathrm{kg}^{-1} \mathrm{dw}$ of $\Sigma \mathrm{C}-\mathrm{PAH}$ only, were observed until June/July 2001, i.e., during the 17 months of the survey. Higher concentrations of sulphur heterocycle compounds and their alkyl homologues were also detected for the same period. The distinct peaks of concentrations of PAHs were detected in a water phase during the whole period from May until July 2000 and at more irregular intervals in the particulate phase in July and September 2000 and in February and April 2001. After July 2001, concentrations of PAHs significantly declined in both the water and the SPM 
Table 2. Concentrations (ng L $\mathrm{L}^{-1}$ ) of dissolved PAHs in offshore and coastal waters before and after the spill. $\Sigma$ TPAH: Sum of the total PAHs as listed in Table 1. $\Sigma$ EPA-PAH: Sum of the 18 PAHs (16 PAHs from the EPA list of priority PAHs, and triphenylene unresolved from chrysene, and benzo[j]fluoranthene unresolved from benzo[ $k]$ fluoranthene): naphtalene, acenaphtylene, acenaphthene, fluorene, phenanthrene, anthracene, fluoranthene, pyrene, benz $[a]$ anthracene, chrysene + triphenylene, benzo $[b]$ fluoranthene, benzo $[k]$ fluoranthene + benzo[j]fluoranthene, benzo[ $a]$ pyrene, indeno[1,2,3-cd]pyrene, dibenz $[a, h]$ anthracene, benzo[ghi]perylene. $\Sigma$ EPA C-PAH: Sum of alkylnaphthalenes, flourenes, phenanthrenes/anthracenes, alkyl-fluoranthenes/pyrenes, alkyl-chrysenes, alkyl-benzofluoranthenes. $\Sigma$ PAH: Sum of phenanthrene, anthracene, fluoranthene, pyrene, benz $[a]$ anthracene, chrysene + triphenylene, benzo[b]fluoranthene, benzo $[k] f l u o r a n t h e n e+$ benzo[ $j]$ fluoranthene, benzo $[a]$ pyrene, benzo[e]pyrene, indeno[1,2,3-cd]pyrene, dibenz $[a, h]$ anthracene, benzo[ghi]perylene. $\Sigma$ C-PAH: Sum of alkyl-phenanthrenes/anthracenes, alkyl-fluoranthenes/pyrenes, alkyl-chrysenes, alkyl-benzofluoranthenes. $\Sigma$ SPAH: Sum of unsubstituted dibenzothiophene and three benzonaphthothiophenes. $\Sigma$ C-SPAH: Sum of alkyl-substituted dibenzothiophnes and benzonaphthothiophenes. All alky-substituted compounds used for summed concentrations as in the Table 1.

\begin{tabular}{|c|c|c|c|c|c|c|c|c|c|}
\hline Location & & $\begin{array}{c}\text { Salinity } \\
\text { PSU }\end{array}$ & $\Sigma$ ТРАН & $\Sigma$ EPA-PAH & \multicolumn{3}{|c|}{ Concentrations $\left(\mathrm{ng} \mathrm{L}^{-1}\right)$} & $\Sigma \mathrm{SPAH}$ & $\Sigma \mathrm{C}$-SPAH \\
\hline & & \multicolumn{8}{|c|}{ Pre-spill Feb. 1999} \\
\hline \multirow[t]{2}{*}{ Off-shore } & $\min$ & 34.05 & 2.46 & 0.82 & 1.48 & 0.44 & 0.29 & 0.02 & 0.10 \\
\hline & $\max$ & 35.59 & 5.66 & 1.72 & 3.65 & 0.68 & 0.53 & 0.05 & 0.23 \\
\hline \multirow[t]{3}{*}{ Coastal } & $\min$ & 26.06 & 4.57 & 1.62 & 2.67 & 0.77 & 0.59 & 0.04 & 0.17 \\
\hline & $\max$ & 34.73 & 8.43 & 2.75 & 5.41 & 1.14 & 1.01 & 0.06 & 0.33 \\
\hline & & \multicolumn{8}{|c|}{ Post-spill 2000} \\
\hline \multirow[t]{2}{*}{ Off-shore } & $\min$ & 27.46 & 3.93 & 0.70 & 2.93 & 0.44 & 1.19 & 0.04 & 0.21 \\
\hline & $\max$ & 35.36 & 14.0 & 2.83 & 8.85 & 1.22 & 3.48 & 0.45 & 3.16 \\
\hline \multirow[t]{2}{*}{ Coastal } & $\min$ & 28.04 & 23.5 & 3.91 & 17.1 & 2.69 & 10.0 & 0.40 & 1.88 \\
\hline & $\max$ & 33.05 & 54.9 & 8.75 & 41.2 & 6.31 & 25.2 & 1.11 & 6.60 \\
\hline \multirow{3}{*}{ Coastal } & & \multicolumn{8}{|c|}{ Survey 2000-2002 } \\
\hline & $\min$ & 18.09 & 2.97 & 0.85 & 1.69 & 0.42 & 0.63 & 0.03 & 0.17 \\
\hline & $\max$ & 34.43 & 152 & 20.9 & 118 & 14.0 & 71.4 & 2.90 & 12.5 \\
\hline \multicolumn{10}{|c|}{ Off-shore 2002} \\
\hline Off-shore & $\min$ & 33.59 & 2.15 & 1.07 & 0.91 & 0.42 & 0.38 & 0.02 & 0.13 \\
\hline & $\max$ & 34.81 & 3.87 & 1.59 & 1.99 & 0.71 & 0.75 & 0.03 & 0.23 \\
\hline
\end{tabular}

phase and stayed systematically lower until the end of the survey in May 2002. This drop in the PAH concentrations in the waters of the Pen Bron station coincides with the end of the removal of fuel from the sandy sediments and additional clean-up activities. Despite this, in relation to the pre-spill reference data, especially in the water phase, the relative amounts of alkyl substituted PAHs remained higher during the whole period of the survey until May 2002. Indeed, the mean ratio of $\Sigma \mathrm{PAH} / \Sigma \mathrm{C}$-PAH in the water phase for the survey set of data was $0.28 \pm 0.12(N=27)$ at Pen Bron station and was $0.51 \pm 0.04(N=3)$ for pre-spill coastal control stations located at Croisic and Belle Ile. The variation of concentrations was very wide according to the survey data and also when compared to reference pre-spill data. For the survey data, the maximum detected a roughly twenty fold increase in the concentrations of unsubstituted dissolved PAHs and it was approximately between 50 to 100 times higher for alkyl PAHs and sulphur compounds. In a particulate phase the increase in concentrations of parent PAHs was not significant whereas it was quite substantial for alkyl and sulphur derivatives ranging from around 15 to 50 times higher (excluding the two highest ratios for the survey data).

\subsection{Sediments}

\section{Pre-spill contamination of surface sediments by PAHs}

The comprehensive qualitative and quantitative examination of the contamination of surface sediments by PAHs before the Erika disaster was made in the Bay of Biscay and along the French coast, covering the sampling stations located between Penmarc'h Point in the North and Adour estuary, near the Spanish frontier, in the South (Fig. 2). The summary statistics of the concentration distributions features in Figure 7. The mean and median of unsubstituted PAH summed concentrations in the sediments were 579 and $381 \mu \mathrm{g} \mathrm{kg}^{-1} \mathrm{dw}$ sediment $(N=92)$, respectively. The first and third quartiles ranged from 140 to $600 \mu \mathrm{g} \mathrm{kg}^{-1} \mathrm{dw}$, which correspond to the 25 th and 75 th percentiles respectively. The highest concentrations above $2000 \mu \mathrm{g} \mathrm{kg}^{-1} \mathrm{dw}$ were detected at only a few stations with a maximum above $5000 \mu \mathrm{g} \mathrm{kg}^{-1} \mathrm{dw}$. These results show that the baseline chronic contamination of the benthic sediments by PAHs along the French Biscay coast was fairly low in 1999 and compares to the OSPAR background reference concentrations of parent PAHs in the sediments for the North-East Atlantic, ranging from 25 to $125 \mu \mathrm{g} \mathrm{kg}^{-1} \mathrm{dw}$ 
Table 3. Concentrations $\left(\mu \mathrm{g} \mathrm{kg}^{-1} \mathrm{dw}\right)$ of particulate PAHs in suspended particulate matter in offshore and coastal waters before and after the spill. Summed concentrations as in Table 2. Pre-spill samples were collected in June 1995 in off-shore and coastal waters of Loire estuary; fiber-glass filters with SPM were stored frozen at $-20{ }^{\circ} \mathrm{C}$ in the sampling bottles.

\begin{tabular}{|c|c|c|c|c|c|c|c|c|}
\hline \multicolumn{9}{|c|}{$\Sigma \mathrm{EPA}$} \\
\hline \multirow[t]{2}{*}{ Location } & & $\Sigma \mathrm{TPAH}$ & $\Sigma$ EPA-PAH & C-PAH & $\Sigma \mathrm{PAH}$ & $\Sigma \mathrm{C}-\mathrm{PAH}$ & $\Sigma \mathrm{SPAH}$ & $\Sigma \mathrm{C}-\mathrm{PAH}$ \\
\hline & & \multicolumn{7}{|c|}{ Concentrations $\left(\mu \mathrm{g} \mathrm{kg}^{-1}\right)$} \\
\hline & \multicolumn{8}{|c|}{ Pre-spill 1995} \\
\hline Off-shore & $\min$ & 108.2 & 33.53 & 62.05 & 28.29 & 20.82 & 1.87 & 7.17 \\
\hline \multirow[t]{2}{*}{ Coastal } & $\max$ & 2578 & 1115 & 883.6 & 1128 & 434.3 & 29.75 & 74.23 \\
\hline & \multicolumn{8}{|c|}{ Post-spill 2000} \\
\hline \multirow[t]{2}{*}{ Off shore } & $\min$ & 173.3 & 56.81 & 76.82 & 42.97 & 47.71 & 2.99 & 7.52 \\
\hline & $\max$ & 290.8 & 129.6 & 156.2 & 140.5 & 111.5 & 5.55 & 18.40 \\
\hline \multirow[t]{3}{*}{ Coastal } & $\min$ & 1178 & 361.2 & 554.9 & 300.1 & 421.5 & 17.38 & 81.60 \\
\hline & $\max$ & 10610 & 1649 & 7541 & 1689 & 5992 & 190.9 & 1130 \\
\hline & \multicolumn{8}{|c|}{ Survey 2000-2002 } \\
\hline \multirow[t]{3}{*}{ Coastal } & $\min$ & 123.0 & 40.31 & 72.00 & 36.26 & 44.86 & 1.38 & 5.19 \\
\hline & $\max$ & 22551 & 2506 & 16564 & 2801 & 15347 & 395.9 & 2548 \\
\hline & \multicolumn{8}{|c|}{ Salt marshes 2002} \\
\hline \multirow[t]{2}{*}{ Etier } & $\min$ & 233.5 & 110.96 & 93.11 & 115.44 & 65.49 & 3.46 & 8.39 \\
\hline & $\max$ & 832.0 & 334.5 & 398.3 & 359.5 & 332.6 & 14.77 & 35.41 \\
\hline \multirow[t]{5}{*}{ Aderne } & $\min$ & 4.38 & 1.12 & 2.59 & 0.95 & 0.81 & 0.04 & 0.03 \\
\hline & $\max$ & 81.31 & 19.58 & 59.44 & 11.96 & 16.36 & 0.43 & 1.77 \\
\hline & \multicolumn{8}{|c|}{ Off-shore 2002} \\
\hline & $\min$ & 474.2 & 207.2 & 168.5 & 217.1 & 96.04 & 9.98 & 12.16 \\
\hline & $\max$ & 1322 & 588.1 & 501.3 & 620.6 & 350.6 & 27.08 & 63.66 \\
\hline
\end{tabular}

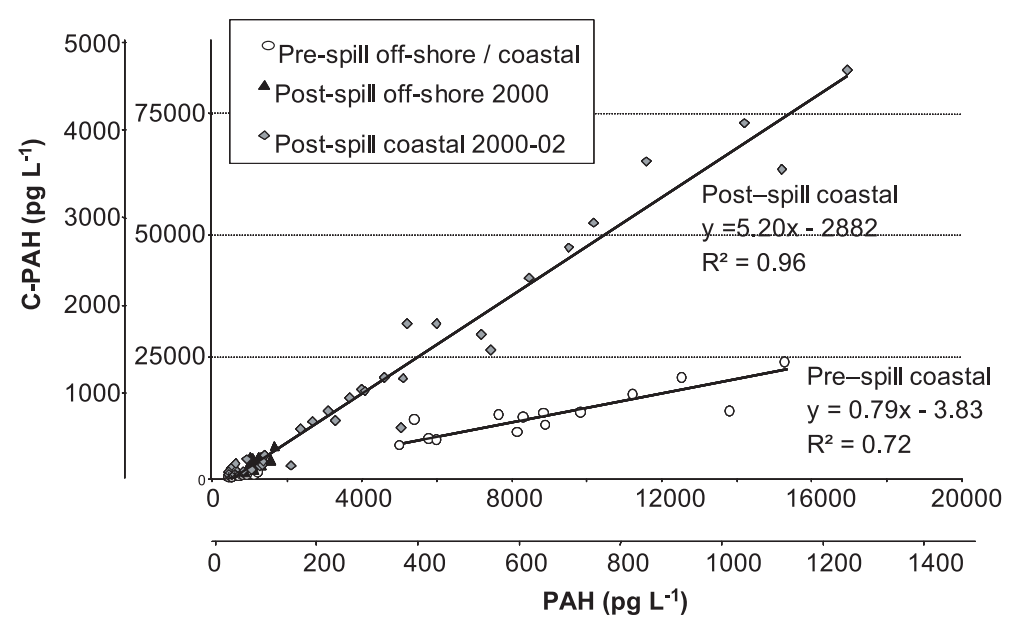

Fig. 5. Relationship between unsubstituted $\Sigma$ PAH and their alkyl substituted homologues $\Sigma$ C-PAH dissolved (pg L $\left.{ }^{-1}\right)$ in water phase before and after Erika oil spill.

(OSPAR 2000). These levels of PAHs are characteristic for surface sediments of present-day contamination by PAHs of regions situated away from the industrialized and urban areas, direct sources of these compounds. In fact, baseline contamination of Biscay surface sediments by unsubstituted PAHs is also comparable with the contamination levels by PAHs in high altitude (above $2000 \mathrm{~m}$ ) Pyrenean and Alpine lakes (Fernandez et al. 1999; Fernandez et al. 2000). These lakes receive PAHs almost exclusively from atmospheric fallout.
The geographical distribution of PAHs in surface sediments along the French Biscay coast show that high levels of this chronic contamination were mainly related to point sources of urban, port and industrial areas such as Lorient, Quiberon, St. Nazaire (Loire river estuary), Arcachon and Bilbao (Basque coast). Furthermore, the bathymetric gradients of PAH contamination were discernible with generally decreasing concentrations in deeper sediments. On the other hand, a more heterogeneous distribution of PAHs was 

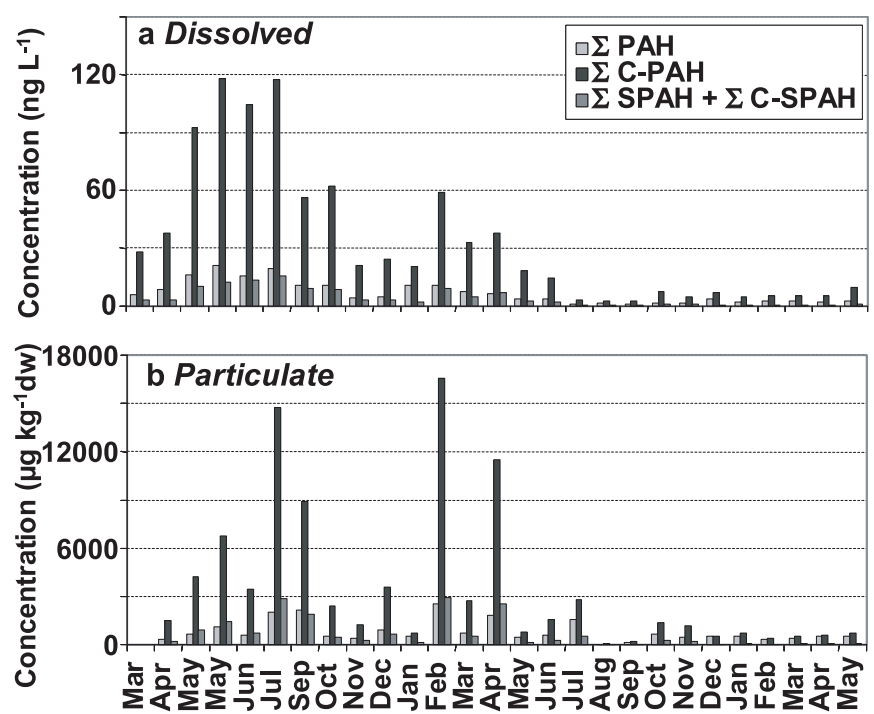

Fig. 6. Temporal variations of different suites of summed concentrations of dissolved ( $\left.\mathrm{pg} \mathrm{L}^{-1}\right)$ (a) and particulate $\left(\mu \mathrm{g} \mathrm{kg}^{-1} \mathrm{dw}\right)$ (b) hydrocarbons ( $\Sigma$ PAH, $\Sigma$ C-PAH, and $\Sigma$ SPAH $+\Sigma$ C-SPAH) in coastal waters at Pen Bron site, from March 2000 to May 2002.

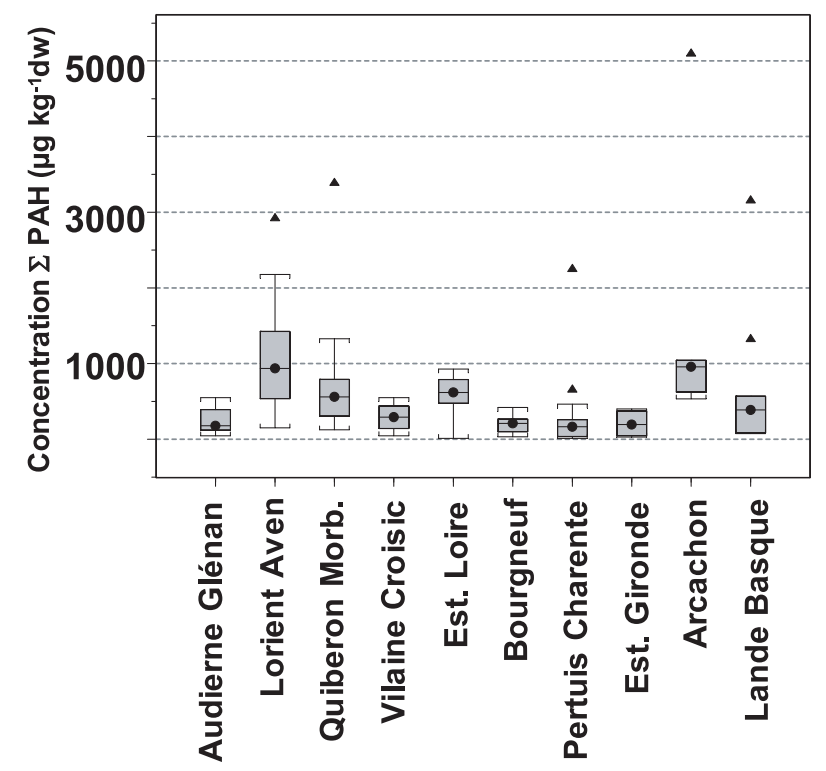

Fig. 7. Concentrations $\left(\mu \mathrm{g} \mathrm{kg}^{-1} \mathrm{dw}\right)$ of $\Sigma$ PAH in surface sediments of the Bay of Biscay before the Erika oil spill.

generally related to grain-size distribution of the coarser fraction of sandy particles, sometimes present in a higher proportion in shallow sediments. It is also worth noting that normalisation in the percentage of fine silt particles $(<63 \mu \mathrm{m})$ of the sediments did not change the overall picture of spatial distribution of baseline sediment contamination by PAHs in the Bay of Biscay.

Finally, regardless of significant differences in $\mathrm{PAH}$ concentrations in the sediments of the Bay of Biscay and the multiple sources of this chronic contamination, their chemical composition was surprisingly constant. Distinctive characteristics of this PAH pattern included: (1) a lower proportion of alky-homologues, with a practically constant ratio of the

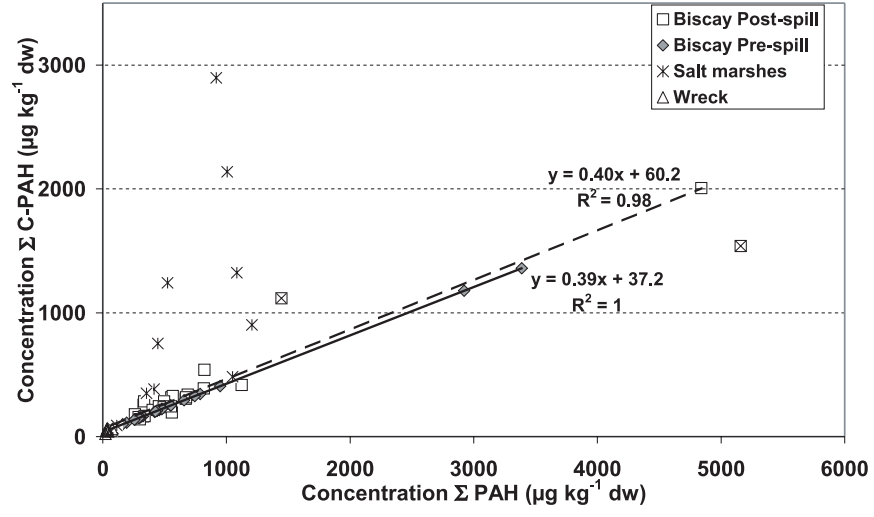

Fig. 8. Relation between unsubstituted $\Sigma$ PAH and alkyl substituted $\Sigma$ C-PAHs in surface sediments $\left(\mu \mathrm{g} \mathrm{kg}^{-1} \mathrm{dw}\right)$ of Biscay Bay before and after the Erika oil spill; regression curves only for two sets of data for subtidal sediments (Biscay pre- and post-spill); two stations (00-42 Loire estuary and 00-66 Quiberon were excluded from the regression) in the post-spill set of data.

summed concentrations of $\Sigma \mathrm{C}-\mathrm{PAH} / \Sigma \mathrm{PAH}$, (2) a higher proportion of four-, five- and six-ring PAHs (including: fluoranthene, pyrene, chrysene, benzofluoranthenes, benz $[e]$ pyrene, benzo $[a]$ pyrene, indeno $[c d]$ pyrene and benzo[ghi]perylene) and (3) alkyl- phenanthrenes, pyrenes and chrysenes concentrations that decreased with increasing substitution. This fairly even pattern of PAH composition corresponds to a persistent airborne and river-borne mixture of chemically stable compounds associated with solid particles, mainly resulting from combustion processes (Gschwend and Hites 1981) and deposited in coastal sediments of the Bay of Biscay. For this set of data, it must also be noted that a perfect correlation $\left(R^{2}=1\right)$ between the summed concentrations of unsubstituted PAHs and alky-PAHs was determined (Fig. 8).

\section{Post-spill subtidal and intertidal sediment contamination by $\mathrm{PAHS}$}

Concentrations of unsubstituted and alkyl-PAHs in subtidal and intertidal sediments of Guérande and Mès salt marshes are described (Table 4). Even though slightly higher mean (822 and $510 \mu \mathrm{g} \mathrm{kg}^{-1} \mathrm{dw}$ ) and median (427 and $296 \mu \mathrm{g} \mathrm{kg}^{-1} \mathrm{dw}$ ) concentrations of parent and alkyl hydrocarbons were determined in post-spill samples respectively (Fig. 7 and Table 4), at a number of subtidal sediment locations, the levels and chemical patterns of PAHs did not significantly change after the Erika oil spill (Fig. 9). These are all stations sampled at the same locations in 1999 and in 2000 at Audierne Bay, Glénan, Aven, Belon, Laiita, Lorient, Etel, Quiberon and Morbihan, i.e., in the region situated north of the Bay of Vilaine, as well as an additional number of southern stations in the Pertuis Breton and near Noirmoutier. It may also be noted that the subtidal sediments of heavily contaminated shorelines by stranded Erika fuel at Vilaine Bay, generally showed neither the Erika$\mathrm{PAH}$ pattern nor the higher post-spill concentrations. In fact, these stations can not be distinguished from their pre-spill stations by $\Sigma \mathrm{C}-\mathrm{PAH} / \Sigma \mathrm{PAH}$ ratios. The unsubstituted PAHs were very highly correlated with their alkyl homologues in both pre- and post-spill sets of data $\left(R^{2}=1, N=27\right.$ and 
Table 4. Concentrations $\left(\mu \mathrm{g} \mathrm{kg}^{-1} \mathrm{dw}\right)$ of $\Sigma$ PAH and $\Sigma$ C-PAH in sediment samples before and after the spill: minimum (Min), maximum (Max), first quartile (1st Qu.), third quartile (3rd Qu.), mean, median, and number of data $(N)$. Summed concentrations as in Table 2.

\begin{tabular}{|c|c|c|c|c|c|c|c|c|}
\hline & & Min & Max & 1st Qu. & 3rd Qu. & Mean & Median & $N$ \\
\hline \multicolumn{9}{|l|}{ Pre-spill } \\
\hline \multirow[t]{2}{*}{ Biscay } & $\Sigma \mathrm{PAH}$ & 46 & 3388 & 293 & 550 & 618 & 438 & 27 \\
\hline & $\Sigma \mathrm{C}-\mathrm{PAH}$ & 55 & 1360 & 152 & 252 & 278 & 208 & 27 \\
\hline \multicolumn{9}{|l|}{ Post-spill } \\
\hline \multirow[t]{2}{*}{ Biscay } & $\Sigma \mathrm{PAH}$ & 20 & 5159 & 335 & 683 & 822 & 510 & 30 \\
\hline & $\Sigma \mathrm{C}-\mathrm{PAH}$ & 13 & 2008 & 201 & 388 & 427 & 296 & 30 \\
\hline \multirow[t]{2}{*}{ Salt Marshes } & $\Sigma \mathrm{PAH}$ & 113 & 1205 & 563 & 1065 & 795 & 962 & 6 \\
\hline & $\Sigma \mathrm{C}-\mathrm{PAH}$ & 90 & 2897 & 789 & 1935 & 1350 & 1113 & 6 \\
\hline \multirow[t]{2}{*}{ Wreck } & $\Sigma \mathrm{PAH}$ & 22 & 76 & 26 & 39 & 37 & 32 & 7 \\
\hline & $\Sigma \mathrm{C}-\mathrm{PAH}$ & 15 & 66 & 32 & 58 & 44 & 47 & 7 \\
\hline
\end{tabular}

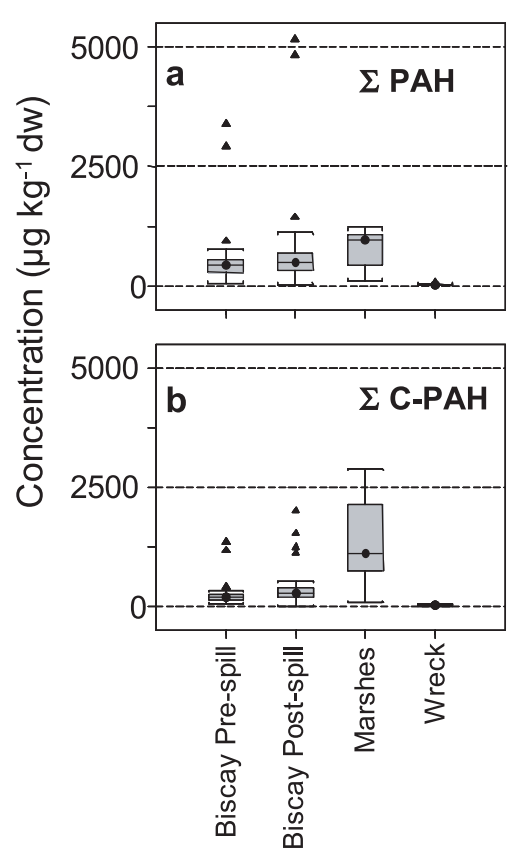

Fig. 9. Concentrations $\left(\mu \mathrm{g} \mathrm{kg}^{-1} \mathrm{dw}\right)$ of unsubstituted $\Sigma$ PAH (a) and alkyl substituted $\Sigma$ C-PAH (b) in surface sediments before and after the Erika oil spill.

$R^{2}=0.98, N=23$ ) and the slopes of their linear regressions did not change (Fig. 8).

The intertidal sediments of Vilaine Bay sampled in a non protected zone of salt marshes (Guérande and Mès) and in the Croisic Tract and Bourgneuf Bay show consistent contamination patterns of Erika-PAHs with a higher proportion of alkylhomologues (Fig. 9). For instance, the median concentrations of parent and alkyl-PAHs were 963 and $1113 \mu \mathrm{g} \mathrm{kg}^{-1} \mathrm{dw}$ respectively in the intertidal sediments of salt marshes. Only a few stations of shallow subtidal sediments of the Loire estuary and Bourgneuf Bay revealed a relatively weak contamination by Erika-PAHs. These stations were excluded from regression calculation for post-spill samples in Figure 8. Among the lowest concentrations of PAHs were those determined in relatively deeper bottom sediments in the Erika wreck area (Table 4). Despite very low concentrations ranging from 22 to $76 \mu \mathrm{g} \mathrm{kg}^{-1} \mathrm{dw}$ of unsubstituted PAHs and from 15 to $66 \mu \mathrm{g} \mathrm{kg}^{-1} \mathrm{dw}$ of alkyl-homologues, the chemical patterns of $\mathrm{PAH}$ composition characterized mainly by higher relative concentrations of alkyl- phenanthrenes and chrysenes also suggest low contamination of the sediments by Erika-PAHs at this location.

\subsection{Intertidal marine molluscs}

\section{Pre-spill PAH concentrations and distribution profile}

Concentrations of PAHs in mussels and oysters collected for the French Mussel Watch and in samples collected a few days before the fuel washed up on shore give pre-spill reference values in the area. These concentrations are essential for comparing contamination levels before and after the spill, and to establish restoration criteria upon a baseline reference value.

The concentration of the sum of unsubstituted PAHs $(\Sigma \mathrm{PAH})$ and the sum of alkyl substituted homologues $(\Sigma \mathrm{C}$ $\mathrm{PAH})$ recorded in these areas were $128 \mu \mathrm{g} \mathrm{kg}^{-1}$ dry weight (median value, $n=21$ ) and $88 \mu \mathrm{g} \mathrm{kg}^{-1} \mathrm{dw}$ (median value, $n=21$ ) respectively, whereas the concentrations of sulfur heterocyclic analogues DBT, $\Sigma$ C-DBT, $\Sigma$ BNT and $\Sigma$ C1-BNT were $0.7,13.5,2.7$ and $2.0 \mu \mathrm{g} \mathrm{kg}^{-1} \mathrm{dw}$ respectively. The PAH distribution pattern in these reference samples is dominated by unsubstituted compounds indicative of combustion-derived contamination.

Post-spill concentrations - Figure 10 shows the distribution of frequency for summed concentrations of PAHs in molluscs during the survey conducted on the coasts impacted by the Erika spill from late December 1999 to December 2002 $(n=226)$. The distribution of frequency for $\Sigma$ PAH shows a dissymmetrical profile, with $83 \%$ of the samples being above the median reference concentration levels $\left(128 \mu \mathrm{g} \mathrm{kg}^{-1} \mathrm{dw}\right)$, and a relative high frequency $(8 \%)$ for samples in the $1000-1999 \mu \mathrm{g} \mathrm{kg}^{-1} \mathrm{dw}$ range. The distribution of frequency for $\Sigma$ C-PAH (Fig. 10) shows that more than $95 \%$ of the samples collected during the three-year period of the study presented higher concentration levels than the median reference concentration level $\left(88 \mu \mathrm{g} \mathrm{kg}^{-1} \mathrm{dw}\right)$. Maximum concentration 

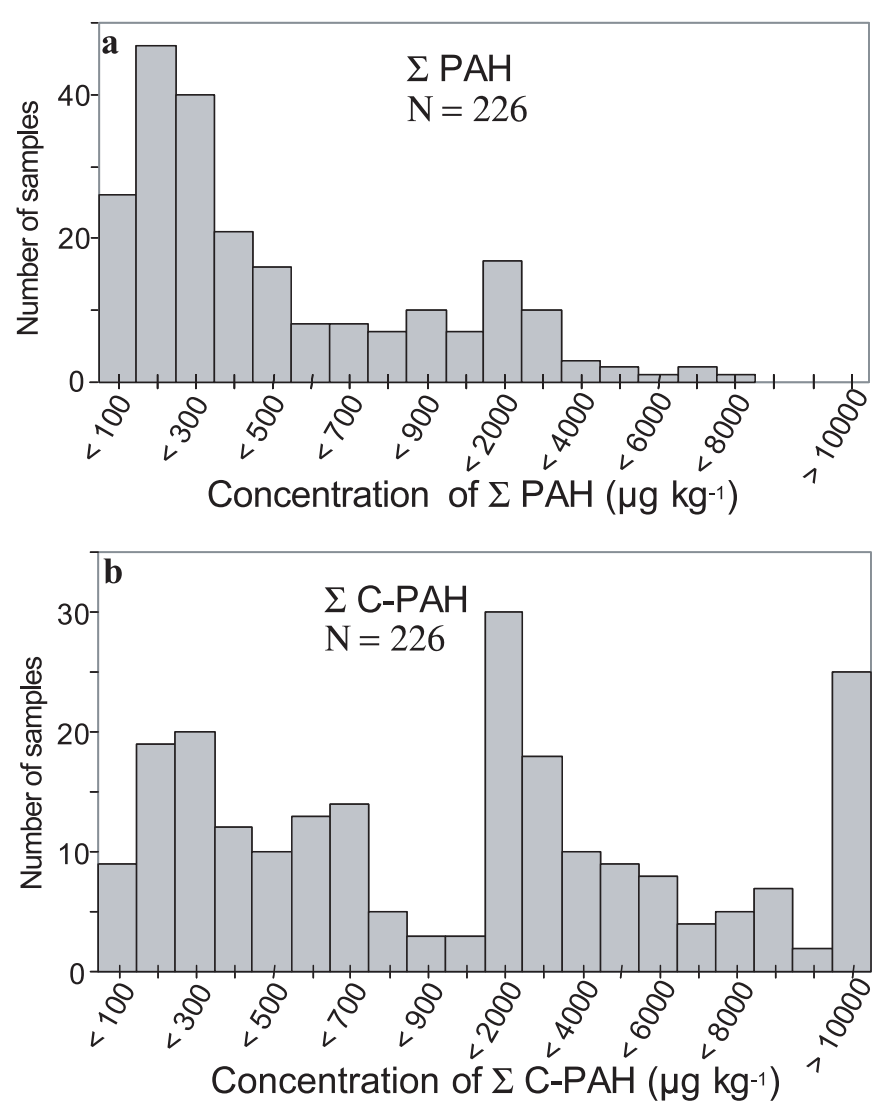

Fig. 10. Distribution of frequency of $\Sigma$ PAH (A) and $\Sigma$ C-PAH (B) $\left(\mu \mathrm{g} \mathrm{kg}^{-1} \mathrm{dw}\right)$ in marine molluscs along the French coasts impacted by the Erika oil spill over a 3-years survey time (January 2000 to December 2002). $\Sigma$ PAH: Sum of phenanthrene, anthracene, fluoranthene, pyrene, benz $[a]$ anthracene, chrysene + triphenylene, benzo[b]fluoranthene, benzo[k]fluoranthene, benzo[j]fluoranthene, benzo[ $[a]$ pyrene, benzo[e]pyrene, indeno[1,2,3-cd]pyrene, dibenz $[a h]$ anthracene, benzo[ghi]perylene. $\Sigma$ C-PAH: Sum of alkyl-phenanthrenes/anthracenes, alkyl-fluoranthenes/pyrenes, alkyl-chrysenes, alkyl-benzofluoranthenes.

levels were recorded for mussel samples at the Pen Bron location with $\Sigma$ PAH of $6944 \mu \mathrm{g} \mathrm{kg}^{-1} \mathrm{dw}$ and $\Sigma$ C-PAH of $83481 \mu \mathrm{g} \mathrm{kg}^{-1} \mathrm{dw}$, i.e., at a site where the contamination of waters by dissolved and particulate PAHs was also shown to be the highest (as discussed above).

An example of the temporal variation of the PAH, C-PAH, BNT, C-BNT, DBT and C-DBT concentrations is given in Figure 11 for mussel samples collected at the Pen Bé site, a highly impacted area located in Vilaine Bay (Fig. 3). Concentrations (in $\mu \mathrm{g} \mathrm{kg}^{-1} \mathrm{dw}$ ) in the non-impacted mussels in December 1999 were 180 for the $\Sigma$ PAH and 104 for the $\Sigma$ C-PAH, whereas these levels were respectively 694 and 3200 in January 2000; then 2536 and 20094 in February 2000. The differences observed in PAH concentrations between prespill and maximum post-spill levels (February 2000) show that PAH levels rose 22 times for the $\Sigma$ PAH and 171 times for the $\Sigma$ C-PAH after the disaster (Fig. 11). For BNT and C-BNTs, the maximum increases are 270 times and 1337 times respectively.
The PAH concentration levels subsequently experienced a slow decrease with lower values generally in summer, and increases in October and November. The concentrations of $\Sigma$ C-PAH $\left(353 \mu \mathrm{g} \mathrm{kg}^{-1} \mathrm{dw}\right.$ with $\Sigma \mathrm{PAH} / \Sigma \mathrm{C}$-PAH ratio of $0.52)$ and C1-BNTs $\left(31 \mu \mathrm{g} \mathrm{kg}^{-1} \mathrm{dw}\right)$ in December 2002 were still above reference concentrations of the same suites of compounds in samples collected before the spill (104 and $2 \mu \mathrm{g} \mathrm{kg}^{-1} \mathrm{dw}$ respectively in December 1999). Among the sites still surveyed in December 2002, some of them show concentration levels above the mean reference concentration recorded before the spill (i.e. $128 \mu \mathrm{g} \mathrm{kg}^{-1} \mathrm{dw}$ ) especially in the Loire-Atlantique and the Vendée, whereas in the less impacted sites the concentration levels returned to reference levels.

\section{PAH distribution pattern}

Figure 12 shows the distribution profiles observed in mussels collected from the Pen Bé site, Vilaine Bay, before (December 1999) and after the influx of the fuel onto the coastline (January 2000 and December 2002).

The PAH distribution pattern in molluscs collected after the spill was mainly dominated by alkyl substituted compounds, with $\mathrm{C} 1-, \mathrm{C} 2-$ and $\mathrm{C} 3$ - phenanthrenes/anthracenes, $\mathrm{C} 1$ - and C2- chrysenes and C1- and C2- fluoranthenes/pyrenes being the most abundant. Among the unsubstituted PAHs, chrysene was the most abundant, and pyrene concentrations are higher than fluoranthene for the most contaminated samples. Impacted mussels also revealed high levels of sulfur-containing compounds, especially C-DBTs, BNTs and C-BNTs. The distribution pattern observed in the sample collected in December 2002 was still dominated by alkyl-substituted homologues, which differs significantly from the pattern observed in the reference samples. The degradation of PAHs by molluscs was not significant and thus the distribution pattern observed in molluscs could be used to assess the exposure source. The study of the distribution profiles of individual compounds in molluscs provided evidence of the significant contamination of the molluscs by fuel from the Erika.

The median $\Sigma \mathrm{PAH} / \Sigma \mathrm{C}$-PAH ratio in the organisms before the spill was 1.48 for $n=21$, which differs considerably from the ratio observed in the organisms after the oil spill (median $=0.25, N=226$ ). The relative abundance of alkyl substituted compounds over unsubstituted compounds is used to distinguish different sources of contamination by petroleum or combustion-derived compounds (Gschwend and Hites 1981; Colombo et al. 1989; Wang et al. 1999) and was found to be a good indicator for surveying the contamination of the molluscs from the Erika's fuel.

\section{Discussion}

\subsection{Contamination of environmental compartments by PAHs}

The results obtained for this study indicate that water, SPM and marine molluscs were highly and durably contaminated by PAHs originating from the Erika's heavy fuel oil. The study of subtidal sediments in the Bay of Biscay did not show significant contamination by Erika-PAHs by July 2000. However, 

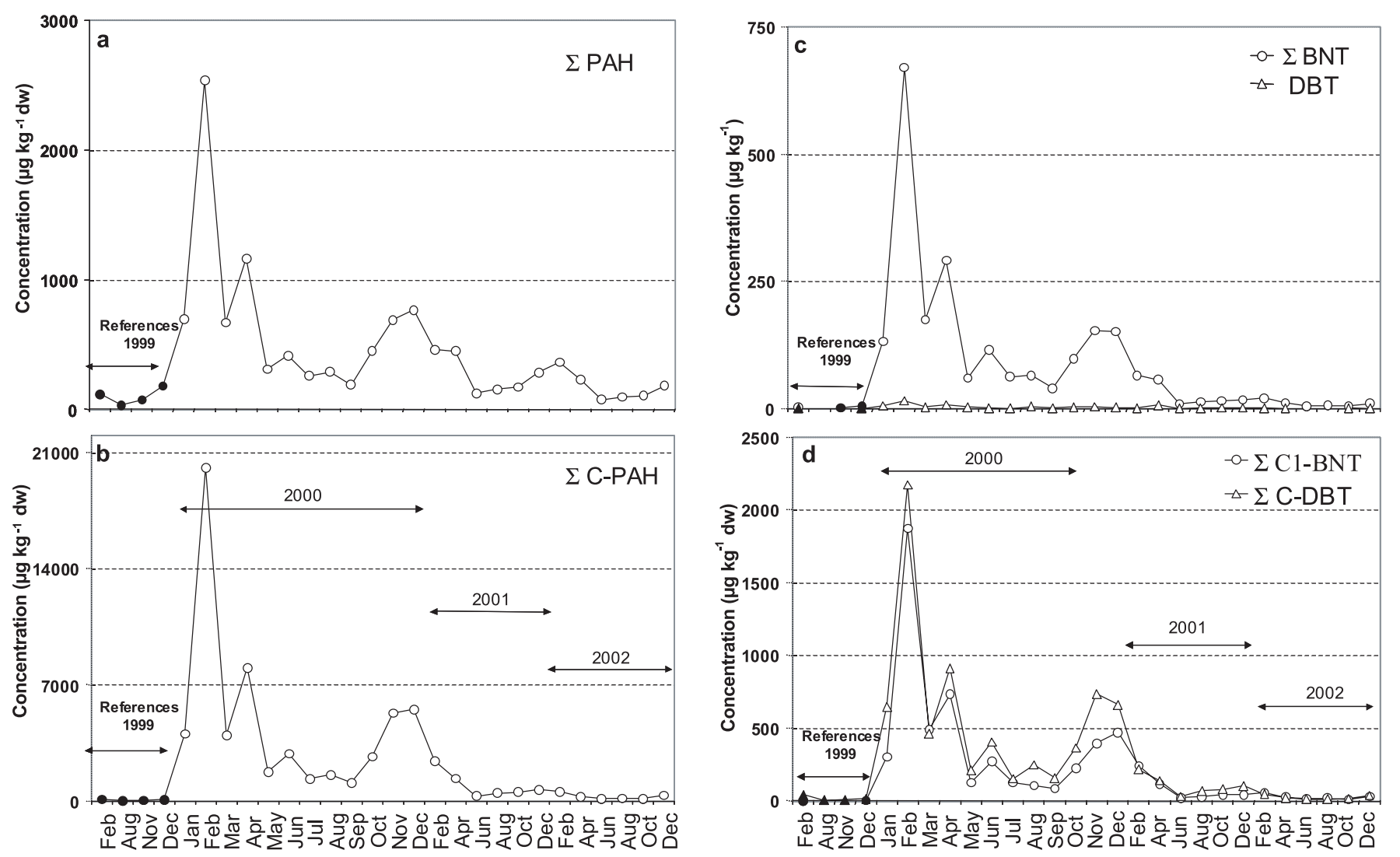

Fig. 11. Temporal variations of $\Sigma$ PAH (a), $\Sigma$ C-PAH (b), $\Sigma$ BNT and DBT (c), $\Sigma$ C1-BNT and $\Sigma$ C-DBT (d) $\left(\mu \mathrm{g} \mathrm{kg}{ }^{-1}\right.$ dw) in mussels at site Pen Bé (Bay of Vilaine).
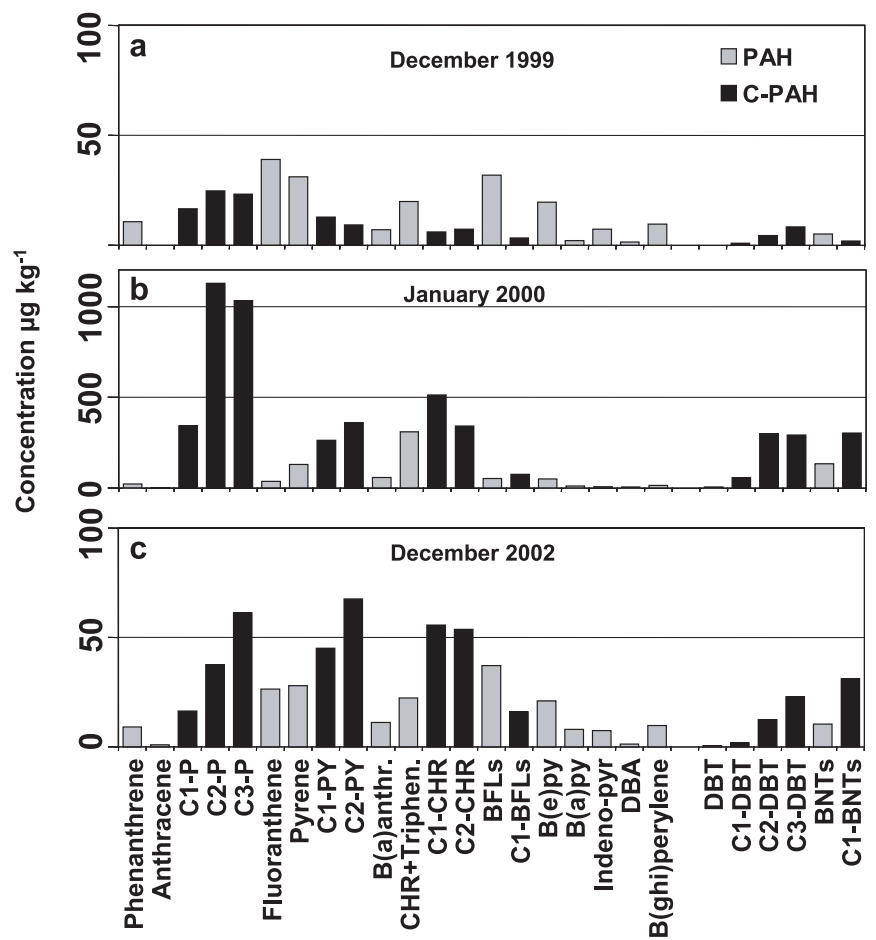

Fig. 12. PAHs distribution profiles in mussels at site Pen Bé (Bay of Vilaine) in December 1999 (a, pre-spill) and after the spill in January 2000 (b) and December 2002 (c). several sites, especially those in Bourgneuf Bay and in the unprotected areas of Guérande and the Mès salt marshes, display a strong contamination of intertidal sediments by Erika-PAHs. These observations will be further discussed below.

\subsection{Water contamination by PAHs}

\section{Washed up fuel slicks on the sea shores as significant reservoirs of PAHs in a water phase}

Our results demonstrate that oiled sea shorelines, including beaches, rocky coasts as well as sandy sediments apparently became reservoirs of spilled Erika fuel, which continued to contaminate seawater, suspended particulate matter and subsequently mussels with PAHs for a relatively long time after the spill. Tidal and storm wave actions and clean-up activities probably dispersed substantial quantities of fuel particles into the water column. Dispersed fuel particles and thicker layers of the floating fuel in a water column supply bulky surfaces for $\mathrm{PAH}$ dissolution, as well as for the direct coating of suspended matter and possibly sediments (Short and Harris 1996a). In respect to this, our temporal survey results at Pen Bron station provide a fairly unique example of the contamination of seawater and suspended particulates by dissolved and particulate PAHs that originate from this type of buried fuel slick under the sandy sediments. It appears that this slick is a persistent 
reservoir which supplies sufficient amounts of PAHs to contaminate a large volume of adjacent seawater at low aqueous concentrations. Despite the sampling of different water masses (salinity varied from 18.1 to 34.4 ) made only once per month during our survey, and the continuous flushing and renewal of large volumes of seawater at the Pen Bron site, a meaningful set of results were obtained relating to dissolved and particulate PAH concentrations in a water phase. This also suggests a rapid mixing in a water column of the dissolved and particulate PAHs originating from the Erika fuel slick buried under sandy sediments. Moreover, a prominent decline in the concentrations of PAHs after the slick removal show that this type of clean-up action was effective in abating environmental chemical contamination, even if higher amounts of the fuel could possibly be dispersed into the water column during these activities

In addition, considering that about $400 \mathrm{~km}$ of shoreline of the Bay of Biscay were contaminated by the Erika's fuel during the first month after the disaster and that common processes of fuel dispersion and PAH dissolution were operating everywhere, it could be expected that very large seawater volumes were actually contaminated by Erika-PAHs (Short and Harris 1996a; Jahns et al. 1991). The results of long-lasting contamination of molluscs by PAHs, and consistent temporal decline, corroborate the hypothesis that for months after the disaster, even relatively small amounts of the Erika's fuel were still entrapped in the environment and continued to supply these compounds to all the environmental compartments of the Bay of Biscay.

However, the extent of the contamination of the water column after major oil spills has probably not been well assessed to date. There are several reasons for this: the inherent difficulties in organising larger scale observation and surveys of the water column contamination in the marine environment, uncertainties associated with the aqueous dynamics of oil dispersion, analytical difficulties pertaining to the analysis of dissolved PAHs and the elevated costs of such surveys. Finally, corroborating Short and Harris' (1996a) hypothesis, reported for the Exxon Valdez oil spill, the chemical patterns of PAH composition in the water phase after the Erika oil spill are analogous to the patterns in weathered Erika fuel, in that dissolution kinetics and not the solubility of individual PAHs control the composition of dissolved PAHs in the water column. In other terms fugacity ratios and dynamic equilibrium between water phase and oil phase control individual PAH dissolution.

\section{Concentrations of PAHs in a water phase}

The reference pre-spill concentrations of dissolved and particulate PAHs determined in this study were equivalent to concentrations obtained in other sea and coastal areas and estuarine waters. Maldonado et al. (1999) have reported concentrations for similar suites of dissolved unsubstituted PAHs for the Eastern Mediterranean 0.1 to $0.4 \mathrm{ng} \mathrm{L}^{-1}$, for the Baltic Sea 0.3 to $0.6 \mathrm{ng} \mathrm{L}^{-1}$, for the North-West of the Black Sea 0.1 to $0.5 \mathrm{ng} \mathrm{L}^{-1}$, for the Chesapeake Bay estuary 3 to $43 \mathrm{ng} \mathrm{L}^{-1}$, and for the Ebro estuary about $2 \mathrm{ng} \mathrm{L}^{-1}$. Our results for dissolved unsubstituted PAHs reported elsewhere were $0.4 \mathrm{ng} \mathrm{L}^{-1}$ for the bay of the Seine and for the Seine estuary ranged from 3 to $8 \mathrm{ng} \mathrm{L}^{-1}$ with the highest concentrations of about $20 \mathrm{ng} \mathrm{L}^{-1}$ for the Rouen urban-harbour area. In addition, OSPAR (OSPAR 2000) has provided as an assessment criterion the background reference concentrations (BRCs) of unsubstituted PAHs ranging from 0.2 to $0.7 \mathrm{ng} \mathrm{L}^{-1}$ for the North-East Atlantic. Together these results confirm that contamination levels before the Erika oil spill in the seawater of the Northern Biscay region by dissolved PAHs were relatively low. However, for the pre-spill assessment, it was also noted that in this region of the Bay of Biscay, relatively elevated concentrations of dissolved low molecular PAHs (ex. naphthalene and alkyl-homologues) could be found in the seawater before the Erika disaster. Therefore, it was suggested that a better estimate of seawater contamination would be a suite of PAHs without low molecular compounds.

Our results show that the concentrations of dissolved and particulate PAHs span several levels after the Erika oil spill. On the other hand, much wider ranges of concentrations are described in the literature covering the concentrations of PAHs in seawater after different oil spills. However, these results do not generally distinguish dissolved and particulate hydrocarbons. For instance, after the Exxon Valdez oil spill Short and Harris (1996a) reported seawater PAH concentrations ranging up to $6 \mu \mathrm{g} \mathrm{L}^{-1}$ for the first period of sampling in waters adjacent to oil slicks washed up onto the beaches, and Law (1978) also reported high concentrations of PAHs in seawater ranging up to $1.7 \mu \mathrm{g} \mathrm{L}^{-1}$ after the Ekofisk blowout. When recalculated, the summed dissolved and particulate PAH concentrations ranged up to $0.4 \mu \mathrm{g} \mathrm{L}^{-1}$ at the Pen Bron station. It is also worth emphasising that after an oil spill very high concentrations of petroleum hydrocarbons including different suites of PAHs could certainly be determined in a water column. Nevertheless, a very careful examination of the sampling conditions, analytical methods, and reporting of the data is seemingly warranted in order to assure the comparability of the data. In fact, a comparison between data on hydrocarbon concentrations after different oil spills is not a straightforward task.

\subsection{Subtidal and intertidal sediment contamination by PAHs}

\section{Benthic sediment contamination by Erika fuel}

After accidental spills, oiled sediments may be significant and persistent sources of the chemical contamination of the marine ecosystems by toxic components (Peterson et al. 2003). The results of water column contamination by PAHs derived from the buried slick under sandy sediments at the Pen Bron station described above, is one of a series of durable chemical contamination arising from sedimented fuel oil. For this reason, it is generally recognized that the assessment of sediment contamination by hydrocarbons after an oil spill such as that of the Erika tanker is also required to better understand the possibly delayed and long-term ecological consequences in the marine ecosystems (Peterson et al. 2003).

The results of our study show that only intertidal sediments and a few isolated locations of subtidal sediments at Vilaine Bay, the Loire estuary and Bourgneuf Bay were contaminated by Erika-PAHs. The failure to systematically detect Erika fuel oil PAHs in subtidal surface sediments at a number of locations situated North of Vilaine Bay and South of Bourgneuf 
Bay, means that the contamination of subtidal sediments by Erika fuel was perhaps confined to heavily oiled shorelines and to shallow subtidal and intertidal sediments. Even in the Vilaine Bay location, more strongly impacted by washed up fuel-oil, no evidence was found of the heavy contamination of the subtidal sediments by Erika-PAHs. In fact, it is also possible that very little of the Erika's fuel reached the bottom by direct deposition from the water column immediately after the spill. The large floating fuel slicks of the Erika's fuel, ruptured very little and these slicks were very compact when they came ashore at the coastlines. This might be a more general characteristic of heavy fuel oil spills such as that of the Erika (Bassin and Ichiye 1977; Short et al. 1996b). On the other hand, a substantial percentage of oil, especially crude oil, entering subtidal sediments after different oil spills, have been reported (O'Clair et al. 1996). These estimates of the proportions of oil reaching sediments vary from 0.5 to $3 \%$ after the Ixtoc blowout (Boehm et al. 1982) and from 8 to $16 \%$ after the Exxon Valdez oil spill (Wolfe et al. 1994), and 8\% after the Amaco Cadiz oil spill (Gundlach et al. 1983). It is also worth noting that some of the assessment studies of sediment contamination by hydrocarbons after different oil spills were quite intensive. For instance, O'Clair and colleagues (1996) have reported the results of analyses of more than 1200 sediment samples for the Exxon Valdez contamination assessment. These study efforts might be necessary since sediment contamination after oil spills may be patchy and unevenly distributed and thus more difficult to detect.

The strategy of our sampling was organized to re-sample multiple stations, where surface sediment samples were already collected before the Erika oil spill in 1999. These samples provide direct comparison with post-spill assessment. The post-spill sampling was made in July 2000, that is 7 months after the disaster. It was believed that a certain lapse of time was needed to disperse, transport and intermix oiled sediment particles at a greater depth and over a wider area. However, this strategy of sampling was not organized to follow the spread of contamination from shorelines to deeper areas. Although we found strong evidence of Erika fuel contamination by PAHs in intertidal sediments, the consequences of this contamination were not followed further. Different mechanisms pertaining to the direct transport of oil to subtidal sediments were reported, such as the direct sinking of oil (Boehm et al. 1982), the sedimentation of oiled particles and biogenically enhanced transport (O'Clair et al. 1996; Galt et al. 1991). However, as was suggested for the Exxon Valdez (O'Clair et al. 1996), we also believe that the most likely path through which Erika fuel spread to shallow near shore subtidal sediments was created by the resuspension of contaminated coarse beach sand particles due to high energy wave action and tidal flushing, by emulsion formation caused by various mechanisms which eventually make oil particles denser than water and by various cleanup activities (Bassin and Ichiye 1977; Short et al. 1996b).

\subsection{Molluscs}

\section{Bioavailability of PAHs to molluscs}

The results described here provide evidence of the chemical impact of the Erika oil spill on the contamination of intertidal molluscs. The contamination of the molluscs by fuel from the Erika was clearly demonstrated by the increase in the concentration levels and by the drastic change in the distribution pattern of compounds in the shellfish before and after the spill. The increase in the contamination levels occurred very rapidly and the maximum $\mathrm{PAH}$ concentration levels at each site were generally observed in late December 1999 just after the influx of the oil on the coastline, and in January 2000 or in February 2000. The observed contamination of the mussels shows that the fuel was available for the organisms through different routes of exposure. Firstly, the direct ingestion by the molluscs of particulate fuel oil was certainly a main pathway to shellfish contamination. In fact, chemical patterns identified in molluscs after the spill were extremely similar to the pattern determined in the weathered fuel. The contamination of the molluscs also resulted directly from the water and SPM intake since these compartments were highly contaminated by dissolved and particle-associated contaminants. As reported by Meador et al. (1995), marine shellfish can also be exposed to PAHs from sediment and dietary sources.

\section{Persistence of the contamination after the spill}

Several months after the spill high concentrations were still observed at specific sites, especially after high tides and major storm events like those usually observed during autumn and winter. The higher mobilization of the fuel resulted in increases in concentration levels during the autumn of 2000 and winter of 2001, and again the autumn of 2001 and winter of 2002 (Fig. 11). This suggests that the fuel still deposited on the coasts was re-introduced into the water, and that this fuel was further available to the organisms. This can be explained by the resuspension of contaminated particles in the water column during storms and by the fact that the fuel deposited on the rocks at the higher parts of the shore flowed back into the waters during high tides. Thus the higher concentrations observed are due to the exposition of molluscs to higher amounts of fuel. Indeed, the PAH pattern in the contaminated samples provides strong evidence of Erika-derived contamination. The increases observed are also attributed to seasonal variations of $\mathrm{PAH}$ concentrations in response to lower metabolizing capacities because of lower temperatures, and higher lipid contents in shellfish tissues in autumn and winter before the spawning period (Law et al. 1999; Baumard et al. 1999; Dyrynda et al. 2000). Higher lipid contents in mollusc tissues give higher amounts of hydrophobic contaminant accumulation.

Moreover, the re-mobilization of the fuel from the oiled sediment may generate high concentrations in surrounding organisms over a long period of time, as shown by the results obtained at the Pen Bron station.

Three years after the spill higher concentrations than those observed before the spill are still to be found in the samples collected from selected sites highly contaminated by the fuel. Such a long-term contamination of molluscs after an oil spill has been previously reported by different authors (McElroy et al. 1989; Short and Harris 1996b; Short and Babcock 1996; Law and Hellou 1999; Peterson et al. 2003). Our results show that an accumulation of PAHs in molluscs occurred rapidly after the spill, and was followed by a slow decrease. The slow decrease in PAH concentrations in the molluscs is explained by 
their slow depuration rates in relation to the temporal characteristics of chemical contamination of the marine environment (Rantamäki 1997).

\section{Conclusion}

(1) The results obtained for this study indicate that water, SPM and marine molluscs, sampled along the French Biscay coast, heavily oiled by spilled fuel from the Erika tanker, were significantly and durably contaminated by PAHs originating from this heavy fuel-oil.

(2) The concentrations of dissolved and particulate PAHs span several levels after the Erika oil spill and show changes in the composition pattern of different suites of PAHs which were characteristic of weathered fuel-oil from the Erika.

(3) The assessment of the chemical contamination in subtidal sediments did not show significant contamination by Erika-PAHs at the period of sampling (July 2000). Several sites of intertidal sediments and only a few isolated locations of shallow subtidal sediments, reveal contamination by ErikaPAHs. These results imply that contamination of the sediments was confined to heavily oiled shorelines and to shallow and intertidal sediments.

(4) The contamination of the molluscs by Erika-PAHs was clearly demonstrated by the increase in the concentration levels and by significant change in the composition pattern of compounds after the oil spill. The direct ingestion of the fuel was certainly one of the main routes of mollusc contamination by PAHs. Subsequent contamination via water and SPM intake prolonged the depuration phase over a long period. Two years after the disaster, the PAH concentrations and the composition in molluscs were characteristic of Erika induced contamination at certain sites. The geographical contiguity of the stations with high concentrations of PAHs in molluses matches the extent of the shoreline contamination by the spilled fuel.

(5) The compositional patterns of PAHs after the Erika oil spill in contaminated water, SPM, molluscs and intertidal sediments constantly included alkyl-substituted phenanthrenes, pyrenes, chrysenes and sulphur dibenzothiophenes in higher relative abundance than those in the pre-spill samples.

(6) Consistent temporal decline in concentrations for water, SPM and molluscs were distinguished.

Acknowledgements. The efforts of many have contributed to the success of this study. Before the spill, the sampling of sediments and mussels carried out within the National Monitoring Network (Réseau National d'Observation - RNO) provided a unique opportunity to compare the results obtained from the samples after the spill. Much extra sampling was carried out immediately after the spill and during the long months of this study. We are thankful to all colleagues at IFREMER who assisted in field sampling and/or with sample preparation. We are also grateful to the crew of the French R/V Thalia for their valuable help during the sampling cruises.

This work has been financed by Ifremer and the French Ministry for the Environment and Sustainable Development (MEDD: Ministère de l'Environnement et du Développement Durable).

\section{References}

Bassin N.J., Ichiye T., 1977, Flocculation behaviour of sediment and oil emulsions. J. Sediment. Petrol. 47, 671-677.

Baumard P., Budzinski H., Garrigues P., Dizer H., Hansen P.D., 1999, Polycyclic aromatic hydrocarbons in recent sediments and mussels (Mytilus edulis) from the Western Baltic Sea: occurrence, bioavailability and seasonal variations. Mar. Environ. Res. 47, 415-439.

Boehm P.D., Barak J.E., Fiest D.L. Elskus A.A., 1982, A chemical investigation of the transport and fate of petroleum hydrocarbons in littoral and benthic environments: The Tsesis oil spill. Mar. Environ. Res. 6, 157-188.

Colombo J.C., Pelletier E., Brochu C.,Khalil M., 1989, Determination of hydrocarbon sources using n-alkane and polyaromatic hydrocarbon distribution indexes. Case study: Rio de la Plata estuary, Argentina. Environ. Sci. Technol. 23, 888-894.

Dyrynda E.A., Law R.J., Dyrynda P.E.J., Kelly C.A., Pipe R.K., Ratcliffe N.A., 2000, Changes in immune parameters of natural mussel Mytilus edulis populations following a major oil spill ("Sea Empress", Wales, UK). Mar. Ecol. Prog. Ser. 206, 155-170.

Fernandez P., Vilanova R.M., Grimalt J.O., 1999, Sediment fluxes of polycyclic aromatic hydrocarbons in European high altitude mountain lakes. Environ. Sci. Technol. 33, 3716-3722.

Fernandez P., Vilanova R.M., Martinez C., Appleby P., Grimalt J.O., 2000, The historical record of atmospheric pyrolytic pollution over Europe registered in the sedimentary PAH from remote mountain lakes. Environ. Sci. Technol. 34, 1906-1913.

Galt J.A., Lehr W.L., Payton D.L., 1991, Fate and transport of the Exxon Valdez oil spill. Environ. Sci. Technol. 25, 202-209.

Gschwend P.M., Hites R.A., 1981, Fluxes of polycyclic aromatic hydrocarbons to marine and lacustrine sediments in the northeastern United States. Geochim. Cosmochim. Acta, 45, 2359-2367.

Gundlach E.R., Boehm P.D., Marchand M., Atlas R.M., Ward D.M., Wolfe D.A., 1983, The fate of Amoco Cadiz oil. Science 221, 122-130.

Jahns H.O., Bragg L., Dash L.C., Owens E., 1991, Natural cleaning of shorelines following the Exxon Valdez oil spill. In: Proceedings of the International oil spill conference. American Petroleum Institute Publication 4529, Washington DC, pp. 167-176.

Law R.J., 1978, Determination of petroleum hydrocarbons in water, fish and sediments following the Ekofisk blow-out. Mar. Pollut. Bull. 9, 321-324.

Law R.J., Hellou J., 1999, Contamination of fish and shellfish following oil spill incidents. Environ. Geosciences 6(2), 90-98.

Law R.J., Kelly C.A., Nicholson M.D., 1999, Polycyclic aromatic hydrocarbons (PAH) in shellfish affected by the Sea Empress oil spill in Wales in 1996, Polycycl. Aromat. Comp. 17, 229-239.

Maldonado C., Bayona J.M., Bodineau L., 1999, Sources, distribution, and water column processes of aliphatic and polycyclic aromatic hydrocarbons in the Northwestern Black Sea water. Environ. Sci. Technol. 33, 2693-2702.

McElroy A.E., Farrington J.W., Teal J.M., 1989, Bioavailability of polycyclic aromatic hydrocarbons in the aquatic environment. In: Metabolism of polycyclic aromatic hydrocarbons in the aquatic environment. Varanasi U, CRC Press, pp. 1-39.

Meador J.P., Stein J.E., Eichert W.L., Varanasi U., 1995, Bioaccumulation of polycyclic aromatic hydrocarbons by marine organisms. Rev. Environ. Contam. Toxicol. 143, 79-165.

O'Clair C.E., Short J.W., Rice S.D., 1996, Contamination of intertidal and subtidal sediments by oil from the Exxon Valdez oil spill. In: Proceedings of the Exxon Valdez oil spill symposium, Am. Fish. Soc. Symp. 18, 61-93. 
OSPAR, 2000, Background reference concentrations (BRCs) and ecotoxicological assessment criteria (EACs) MON 00/5/Info.-E.

Peterson C.H., Rice S.D., Short J.W., Esler D., Bodkin J.L., Ballachey B..E., Irons D.B., 2003, Long-term ecosystem response to the Exxon Valdez oil spill. Science 302, 2082-2086.

Rantamäki P., 1997, Release and retention of selected Polycyclic Aromatic Hydrocarbons (PAH) and their methylated derivatives by the common mussel (Mytilus edulis) in the brackish water of the Baltic Sea. Chemosphere 35, 3, 487-502.

Short J.W., Babcock M.M., 1996, Prespill and postspill concentrations of hydrocarbons in mussels and sediments in Prince William Sound. In: Proceedings of the Exxon Valdez oil spill symposium, Am. Fish. Soc. Symp. 18, 149-166.

Short J.W., Harris P.M., 1996a, Chemical sampling and analysis of petroleum hydrocarbons in near-surface seawater of Prince William Sound after the Exxon Valdez oil spill. In: Proceedings of the Exxon Valdez oil spill symposium. Am. Fish. Soc. Symp. 18, 17-28.

Short J.W., Harris P.M., 1996b, Petroleum hydrocarbons in caged mussels deployed in Prince William Sound after the Exxon Valdez. oil spill. In: Proceedings of the Exxon Valdez oil spill symposium. Am. Fish. Soc. Symp. 18, 29-39.

Short J.W., Jackson T.J., Larsen M.L., Wade T.L., 1996a, Analytical methods used for the analysis of hydrocarbons in crude oil, tissues, sediments, and sea water collected for the natural resources damage assessment of the Exxon valdez oil spill. In: Proceedings of the Exxon Valdez oil spill symposium, Am. Fish. Soc. Symp. 18, 140-148.

Short J.W., Sale D.M., Gibeaut J.C., 1996b, Nearshore transport of hydrocarbons and sediments after the Exxon Valdez oil spill. In: Proceedings of the Exxon Valdez oil spill symposium. Am. Fish. Soc. Symp. 18, 40-60.
Tolosa I.,Bayona J.M., Albaiges J., 1996, Aliphatic and polycyclic aromatic hydrocarbons and sulfur/oxygen derivatives in Northwestern Mediterranean sediments: spatial and temporal variability, fluxes, and budgets. Environ. Sci. Technol. 30, 2495-2503.

Tronczyński J., Moisan K., Munschy C., Truquet I., Dugrais L., Billard G., 2001, Études des empreintes chimiques et d'altération du fioul d'Erika échoué sur les rochers en Pays de la Loire. Proceedings of the Conference Technical lessons learned from the Erika casualty and other oil spills. CEDRE, Brest.

Vallack H.W., Bakker D.J., Brandt I., Broström Lunden E., Brouwer A., Bull K.R., Gough C., Guardans R., Holoubek I., Jansson B., Koch R., Kuylenstierna J., Lecloux A., Mackay D., McCutcheon P., Mocarelli P., Taalman R.D.F., 1998, Controlling persistent organic pollutants - what next? Environ. Toxicol. Pharmacol. 6, 143-175.

Wang Z., Fingas M., Landriault M., Sigouin L., Feng Y., Mullin J., 1997, Using systemic and comparative analytical data to identify the source of an unknown oil on contaminated birds. J. Chromatogr. 775, 251-265.

Wang Z., Fingas M., Shu Y.Y., Sigouin L., Landriault M., Lambert P., Turpin R., Campagna P., Mullin J., 1999, Quantitative characterization of PAHs in burn residue and soot samples and differentiation of pyrogenic PAHs from petrogenic PAHs - the 1994 Mobile burn study. Environ. Sci. Technol. 33, 3100-3109.

Wolfe D.A., Hameedi M.J., Galt J.A., Watabayashi G., Short J., O'Claire C., Rice S., Michel J., Payne J.R., Braddock J., Hanna S., Sale D., 1994, The fate of the oil spilled from the Exxon Valdez. Environ. Sci. Technol. 28, 561A-568A. 